Bol. Zool. e Biol. Mar., N.S., n.o 30, pp. 641-676, São Paulo, 1973

\title{
SOBRE A MORFOLOGIA E ANATOMIA DA CASEARIA SYLVESTRIS SWARTZ
}

\author{
MARIA LÚCIA ABSY* \\ e ORESTES SCAVONE ** \\ * Biologista e bolsista da Fundação de Amparo à \\ Pesquisa do Estado de São Paulo. \\ * Prof. Adjunto - Departamento de Botânica do \\ Instituto de Biociências da U.S.P
}

RESUMO

O presente trabalho visou um melhor conhecimento botânico, particularmente anatômico, da Casearia sylvestris Swartz, fornecendo ainda algumas informaçōes fitoquímicas sobre essa espécie medicinal, nativa da flora brasileira.

Considerando a anatomia do axófilo foi realizado um estudo comparativo entre as estruturas jovens e adultas da raiz e do caule, analisando as suas modificações histológicas.

Com relação à folha, baseando-se em alguns estágios de seu desenvolvimento, foi possível demonstrar a origem esquizógena das glândulas de óleo essencial.

Nos órgãos vegetativos e de reprodução foi constatada a presença constante de glândulas de óleo essencial e inclusões de drusas e cristais prismáticos, sendo estes mais freqüentes na casca.

$\mathrm{Na}$ folha foi verificado alto teor de óleo essencial o que justificaria, de certo modo, algumas de suas indicações terapêuticas.

\section{ABOUT THE MORPHOLOGY AND ANATOMY OF CASEARIA SYLVESTRIS SWARTZ}

\section{SUMMARY}

A botanical study on the anatomy and some phytochemical aspects of Casearia sylvestris Swartz were made.

This species is very common on Tropical America, specially in Brasil, where it is popularly known as: "guassatonga", "herva-debugre": "pau-de-lagarto". Its leaves are used in popular medicine mainly in skin diseases as a cicatrizant and antiseptic, and also as a topic anesthetic.

Anatomically, the vegetative structures and the reprodutive one, are characterized by the presence of crystalline inclusions and gland cells containing essential oils. The stomata are of the paracytic

Número especial em homenagem ao Prof. Dr. Paulo Sawaya, no ano jubilar de seu magistério. 
type, the epidermic hairs are unicellulars, non-glandulars with lignin impregnated. stem.

Primary and secondary structures were studied in the root and

The root is protostelic, radiate and diarch, and the stem is of the syphonostelic dissected and ectophloic type, characterized by the presence of prismatic crystals and druses, particularly in the phloematic portion of the cortex. The woody tissue presents uniseriate and biseriate vascular rays and inconspicuous growth rings.

The leaf is dorsiventrally organized, and hypostomatic. It was found in young leaves that the gland cells with essential oils are schizogenous in origin.

A parenchymatic gland cell is characteristically present between the two thecas of the anthers; the pollen grains show a granulous exin and three germinal pores. The ovary presents anatropous ovules.

The fruit contains albuminous seeds with aleuron grains.

The leaves present relatively high values of essentail oils, evidences of flavons and saponins, and negative results in following principles: alkaloids, anthraderivatives, coumarins, tannins.

Chromatographic analysis, it was showed the existence of nine components of the essential oils not identified yet.

\section{1 - INTRODUÇÃO}

A flora brasileira, como fonte de plantas com propriedades medicinais, é um fato reconhecido e proclamado a todo momento. Mors e Rizzini (1966) fazem referência de numerosas espécies úteis da flora brasileira, fornecendo algumas informações para um estudo mais pormenorizado. Convém lembrar ainda que, na Farmacopéia Brasileira, estão incluídas numerosas drogas de origem vegetal, muitas das quais são originadas da nossa flora. A preocupação dos estudiosos nesse campo é a inclusão de drogas nacionais como sucedâneas de similares importadas.

Atualmente o uso em terapêutica de plantas medicinais diminuiu bastante, cedendo lugar aos princípios isolados, puros ou modificados.

Numerosas são as famílias vegetais com representantes medicinais, destacando-se, entre elas, as Flacourtiaceae. Esta família apresenta, segundo Joly (1966), 86 gêneros com cerca de 1.300 espécies encontradas especialmente nas regiões tropicais da América do Sul.

No Brasil, há 14 gêneros e cerca de 90 espécies, sendo o gênero Casearia, o mais difundido (Löfgren, 1917). Joly (1966) diz que 
ocorrem, entre nós, espécies principalmente dos gêneros Xilosma, $C a$ searia e Carpotroche.

A família tem várias espécies com propriedades medicinais, salientando-se: o Hydnocarpus kurzii (King) Warburg, o Hydnocarpus wightiana Blume, originários da India, cujas sementes frescas fornecem o óleo de chaulmugra (oleum chaulmougrae) que foi utilizado no tratamento da lepra; o Carpotroche brasiliensis (Raddi) Endlicher, comum entre nós, fornece o óleo de sapucainha (oleum carpotroche) usado como sucedâneo do anterior. Mingóia (1967), porém, referindose aos antileprosos naturais, diz que os resultados conseguidos com o emprego dos óleos fixos, acima mencionados, são contravertidos, apesar dos casos favoráveis registrados.

O gênero Casearia consta aproximadamente de 160 espécies pantropicais, ocorrendo ainda nas ilhas oceânicas da Polinésia (Gilg, 1925).

Record \& Hess (1942) fazem referência de 25 espécies desse gênero na África e Madagascar, 65 na região que vai da China à Austrália e 70 na América tropical, especialmente no Brasil.

Caminhoá (1844) já fazia referência do uso das Caseárias em terapêutica. $\mathrm{Na}$ literatura compulsada, há referências das aplicações medicinais de algumas espécies desse gênero, destacando-se as seguintes:

C. sculenta Roxburgh - raízes utilizadas na İndia como antidiabético. Basu et Choudhury (1960) isolaram dessa planta três substâncias com ação hipoglicêmica.

C. inaequilatera Cambessedes - empregada, segundo Hoehne (1939), para curar certas moléstias da pele, tendo ainda propriedade anestesiante.

C. lingua Cambessedes - usada popularmente como antifebril e contém muito óleo e resina (Elfstrand, 1897).

C. singularis Eichler - contém óleo graxo nas sementes, sendo usada no tratamento da lepra (Kuhlmann, 1926).

A C. sylvestris Swartz, da família Flacourtiaceae, pertencia anteriormente às Bixaceae (Eichler, 1841/1872). Atualmente, as Flacourtiaceae são encontradas na subordem Flacourtinae, ordem Violales (Melchior, 1964). Essa espécie foi descrita originalmente por Swartz 
em 1797 na "Flora Indiae Occidentalis" (Hooker \& Jackson, 1895), estando também incluída na "Flora Brasiliensis" de Martius (Eichler, 1841/1872).

A C. sylvestris Swartz apresenta, segundo Sleumer (1953), a seguinte sinonimia: C. affinis Gardner; C. capitata (Ruiz et Pavon) Sprengel; Samyda sylvestris (Sw.) Poiret; Chaetocrater capitatum Ruiz et Pavon; Crateria capitata (Ruiz et Pavon) Persoon.

Possolo \& Ferreira (1949), referindo-se a esta espécie diz que é abundante em toda a América tropical. Vai do México as Antilhas e, se estende para o sul, vegetando ainda no Paraguai e Argentina, sendo aqui encontrada em florestas higrófilas (Hauman, 1931). No Brasil, a C. sylvestris Swartz é encontrada em várias regiões, sendo comum no Estado de S. Paulo, mesmo nos arredores da Capital. Le Cointe (1947) faz referência dessa planta na Amazônia, nas regiões do rio Tapajós. Löfgren (1894) menciona sua ocorrência em campos e capoeiras.

Consultando certos autores como: Caminhoá (1844), Martius (1868), Lindman (1906), Silva (1926), Corrêa (1931), Freise (1934) e Andrade (1941), a planta em estudo é conhecida vulgarmente por: "guassatonga", "guassatunga", "vassatonga", "vassatunga", "cassatunga", "herva-de-bugre", "herva-de-lagarto", "herva-de-pontada", "pau-de-lagarto", “café-do-diabo", "chá-de-frade", “apiá-acanoçu”, "pioya”, "lingua-de-tiū", "fruta-de-sahyra", "petumba", "catinguá-verde"

Quanto às aplicações desta espécie em medicina popular, limitar-nos-emos a transcrever alguns empregos citados por certos autores:

Corrêa (1931) faz referência do uso da casca dessa planta como antifebril e que o suco e a decocção das folhas têm a mesma propriedade medicinal.

Hoehne (1939) diz que a "guassatunga", popularmente, é usada em certas moléstias da pele como cicatrizante e antisséptica de feridas, além de ser antifebril e estomáquica. O mesmo autor faz referência do estrato das folhas que tem propriedade anestesiante, podendo ser usada em cirurgia dentária e para acalmar dores de ferimentos recentes, acelerando, ainda, sua cicatrização.

Hoehne, Kuhlmann \& Handro (1941) dizem que as folhas e raízes dessa planta são depurativas e anestesiantes. 
Coimbra (1942) refere-se ao emprego medicinal das folhas, sob diferentes formas farmacêuticas, como febrífugo, depurativo, antireumático, nas manifestações sifilíticas cutâneas, eczemas e úlceras. Diz, ainda, que externamente o decocto é utilizado no tratamento de afecções da pele e feridas.

$\mathrm{Na}$ literatura especializada, foram encontrados numerosos trabalhos, particularmente fitoquímicos, sobre o gênero Hydnocarpus devido ao emprego do óleo de chaulmugra como antileprótico.

No Brasil, o estudo sobre as Flacourtiaceae, visou mais a substituição do óleo de chaulmugra, procedente da Índia, pelo óleo de sapucainha extraído do Carpotroche brasiliensis (Raddi) Endlicher.

Com relação à $C$. sylvestris Swartz, baseando-se na literatura consultada, tem sido pouco estudada sob o ponto de vista botânico e fitoquímico. Possolo \& Ferreira (1949) confirmaram a presença de substâncias alcaloídicas, saponinas e óleo etéreo nas folhas da C. sylvestris Swartz, coletadas no Horto Florestal da Cantareira, em São Paulo. Silva \& Bauer (1970) analisaram o óleo essencial das folhas dessa espécie coletada no Rio Grande do Sul, nos locais denominados Belém Novo, Aberta dos Morros e Lomba do Pinheiro, constataram a elevada porcentagem de terpenos $(77,78 \%)$ e ácido hexanóico $(0,58 \%)$.

Sleumer (1953), estudando as Flacourtiaceae argentinas, faz uma descrição morfológica da $C$. sylvestris Swartz, e ainda considerações sobre a distribuição geográfica dessa espécie.

A C. sylvestris Swartz está incluida na Farmacopéia Brasileira (Silva, 1926), onde se encontra uma descrição morfológica da folha.

O trabalho proposto visa, portanto, contribuir para um melhor conhecimento botânico, particularmente anatômico, fornecendo ainda alguns dados fitoquímicos sobre uma espécie medicinal, nativa da flora brasileira.

\section{2 - PARTE BOTÂNICA}

\section{1 - Material e Método}

O material botânico, utilizado no presente trabalho, foi coletado nas proximidades da Cidade Universitária "Armando de Salles Oliveira", São Paulo, Capital. 
A identificação da espécie foi feita pelo Dr. João Rodrigues Mattos, do Instituto Botânico de São Paulo, e também por comparação com a exsicata existente no Herbário do Departamento de Botânica do Instituto de Biociências da Universidade de São Paulo (SPF), onde consta as seguintes referências:

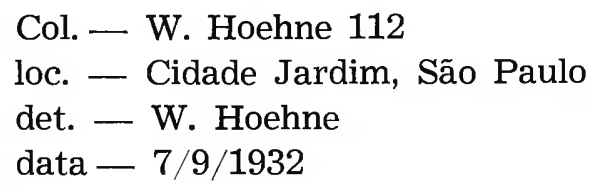

O material que serviu para o estudo morfológico e anatômico, foi coletado em diferentes fases de desenvolvimento da planta.

Para as observações anatômicas, utilizou-se material fresco ou fixado em Allen Bouin e FAA-50\% (Johansen, 1940), sendo os melhores resultados obtidos com este último. A seguir, o material foi desidratado na série alcoólica etílica, com exceção do fruto para o qual foi empregado a série butílica, e incluido em parafina, conforme as técnicas usuais de microtomia. Os cortes foram feitos ao micrótomo e corados com safranina - "fast-green" (Sass, 1951).

A coloração dos tecidos meristemáticos foi feita, segundo Foster (1949), com ácido tânico a $1 \%$ e cloreto férrico a $3 \%$.

Na pesquisa dos grãos de aleurona usou-se, de acordo com Molisch (1923), o ácido pícrico (quantidade suficiente para obter uma solução saturada em álcool absoluto) e a eosina (solução $1 \% \mathrm{em}$ álcool a $95 \%$ ).

Todos esses cortes foram montados entre lâmina e lamínula em bálsamo do Canadá e resina sintética "Harleco"

Com relação ao preparo das lâminas de pólen, para as observações microscópicas, foi utilizado o método de acetólise (Erdtman, 1966) empregado por Santos (1961). Após a preparação, a montagem foi feita em gelatina glicerinada da Kisser (Salgado-Labouriau, 1961).

Os cortes obtidos a mão livre foram diafanizados com hipoclorito de sódio e corados por: hematoxilina de Delafield para celulose; floroglucinol em meio ácido para lignina e cloreto de zinco iodado para celulose e lignina (Harder, 1967).

A presença de óleo essencial e amido foi constatada empregandose respectivamente, o Sudan IV e o lugol (Johansen, 1940); a verifi- 
cação de cálcio nos cristais foi confirmada através da reação com o ácido sulfúrico concentrado (Jensen, 1962). O tanino foi testado com o cloreto férrico a $1 \%$ (Johansen, 1940) e a mucilagem com o azul de metileno a $1 \%$ (Molisch, 1923).

\section{2 - Morfologia Externa}

A C. sylvestris Swartz é planta arbórea atingindo cerca de $3,5 \mathrm{~m}$ de altura e mais ou menos $50 \mathrm{~cm}$ de diâmetro na base.

A casca, com cerca de $1 \mathrm{~mm}$ de espessura, apresenta a superfície externa com coloração parda-acinzentada, rugosa, fendida quase sempre no sentido longitudinal, com placas de líquens e musgos, notandose ainda lenticelas orientadas longitudinalmente; sua superfície interna tem coloração amarelada e estrias longitudinais; possui fratura incompleta fibrosa, sabor e odor não característicos.

O lenho apresenta um cerne de coloração branco-palha, textura fina, sabor e odor não característicos; os anéis de crescimento mostram numerosos "poros" visíveis sob lente. O alburno está representado por uma faixa clara pouco distinta.

As folhas (Fig. 1) são simples, pecioladas, com disposição alterna e dística. O limbo, medindo até $14 \mathrm{~cm}$ de comprimento por $4 \mathrm{~cm}$ de largura, é subcoriáceo, glabro, de forma lanceolada, com bordas serrilhadas, ápice acuminado, base simétrica ou ligeiramente inequilátera; a nervação é reticulada, sendo as nervuras secundárias em número de 7 a 9, afastam-se da nervura principal sob um ângulo que varia de $40^{\circ}$ a $50^{\circ}$ verificando-se, ainda, um retículo de nervuras terciárias; contra a luz, o limbo apresenta pontos translúcidos correspondentes às glândulas de óleo essencial. O pecíolo, com cerca de 0,5 cm de comprimento, é cilíndrico e sulcado na sua porção adaxial.

As flores (Figs. 1 a 6) são pequenas, medindo cerca de $3 \mathrm{~mm}$ de diâmetro, com coloração esverdeada, aromáticas, dispostas em inflorescências axilares de 30 a 50 flores condensadas, cíclicas, actinomorfas, monoclamídeas, hermafroditas e hipóginas.

O verticilo protetor (Figs. 2 e 3 ) é formado, quase sempre, de 5 peças sepalóides, livres e membranosas, dispostas em um verticilo.

O androceu (Fig. 4) consta de 10 estames férteis e de igual número de estaminódios inseridos no terço inferior do verticilo protetor. 


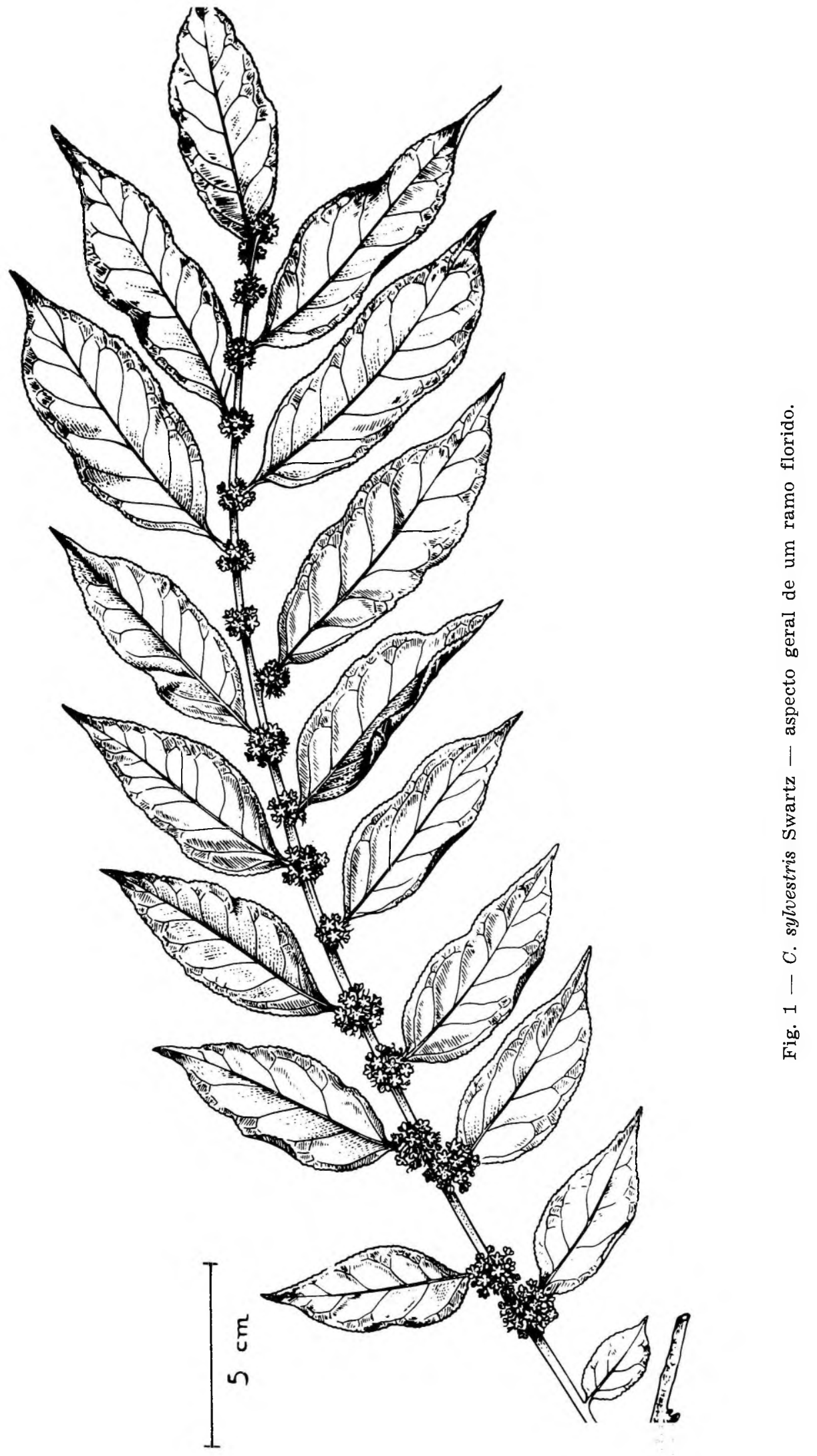



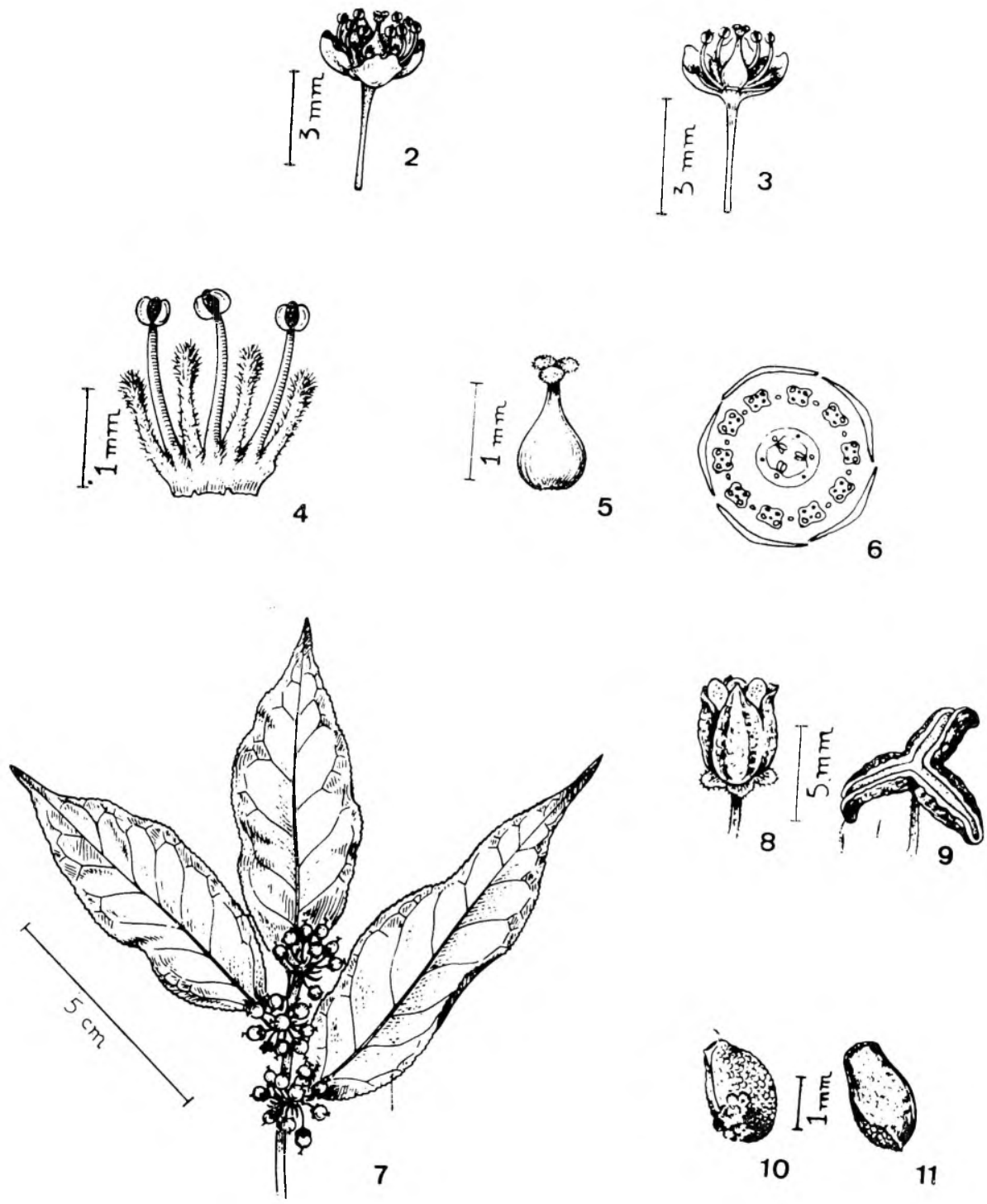

Figs. 2 e 3 - Aspecto geral da flor.

Fig. 4

F'ig. 5

Fig. 6

Fig. 7

Fig. 8

Fig. 9

Fig. 10

Fig. 11

- Detalhe dos estames,

- Detalhe do gineceu.

- Diagrama floral.

- Parte de um ramo frutificado.

- Aspecto geral do fruto.

- Detalhe do fruto após a deiscência.

- Aspecto geral da semente com o arilo.

- Detalhe da semente com arilo parcialmente removido. 
Os estames são livres, regulares, com cerca de $1,5 \mathrm{~mm}$ de comprimento, excedendo de um terço o comprimento dos estaminódios. O filete é simples, pubescente em toda a sua extensão, filiforme, ligeiramente curvo, apresentando a base mais alargada. A antera é bilobada e medifixa, apresentando, caracteristicamente, uma glândula mediana.

Os estaminódios, com cerca de $1 \mathrm{~mm}$ de comprimento, mostram as mesmas características do filete, porém mais pubescente na sua porção apical.

O gineceu (Fig. 5) está bem constituído, apresentando cerca de 2,5 $\mathrm{mm}$ de comprimento. O ovário é súpero, subgloboso, gamocarpelar, tricarpelar, unilocular e multiovulado, medindo cerca de $1 \mathrm{~mm}$ de diâmetro. O estilete é reduzido, com apenas $0,5 \mathrm{~mm}$ de comprimento. O estigma é trífido.

O fruto (Figs. 7, 8 e 9) é uma cápsula septicida, subglobosa, com $6 \mathrm{~mm}$ de diâmetro, mostrando nitidamente as linhas de deiscência.

As sementes (Figs. 10 e 11) são ovóides ou subglobulosas apresentando superfície lisa e coloração parda, medindo $1 \mathrm{~mm}$ de diâmetro, sendo envolvidas por um arilo avermelhado.

\section{$2.3-$ Anatomia}

\subsection{1 - Raiz}

Considerando o estudo anatômico da raiz ainda nova (Figs. 12, $13,14)$, em secções transversais seriadas a partir de seu ápice, verificam-se, no procâmbio, dois polos de diferenciação vascular, originando-se um xilema tipicamente exarco; em secção longitudinal, notam-se vasos anelado e anelo-espiralado. Em relação com os elementos de condução, encontra-se um tecido parenquimático, o mesmo ocorrendo na região da medula onde, porém, esse parênquima se esclerifica. O floema está representado por dois grupos de células, entre os arcos xilemáticos, cujos elementos condutores estão associados às células componheiras e parenquimáticas. No xilema e floema primários, todos os elementos histológicos que entram na sua formação, passam a constituir o sistema axial.

O periciclo é unisseriado e parenquimático, cujas células são dotadas de capacidade meristemática. A endoderme é distinta, mostrando as estrias de Caspary. O parênquima cortical é formado por 


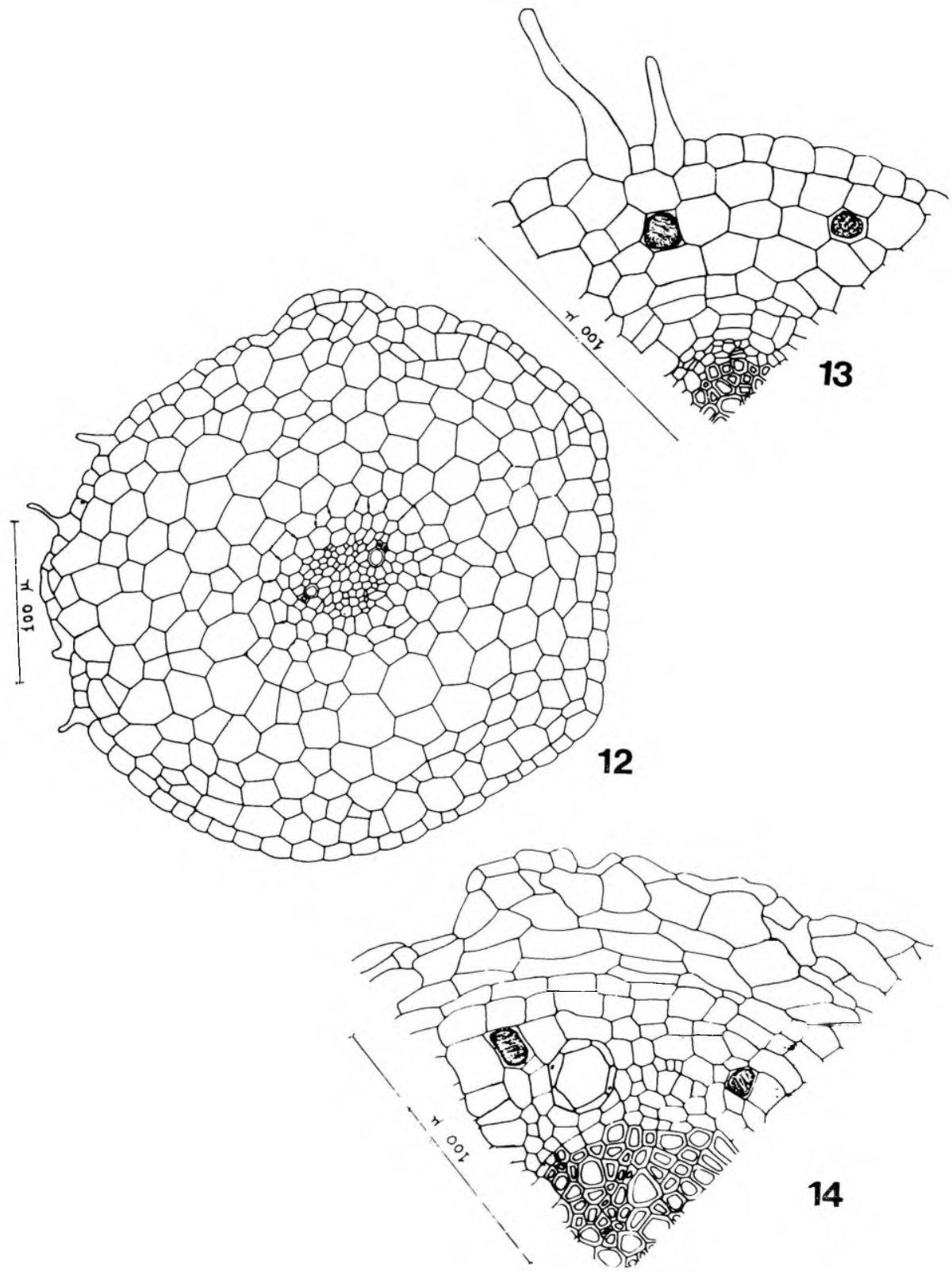

Fig. 12 - Aspecto geral da estrutura primária da raiz.

Fig. 13 - Detalhe anatômico da raiz, mostrando início das divisões periclinais do periciclo.

Fig. 14 - Aspecto da anatomia da raiz, numa fase preparatória para a formação do felogênio. 


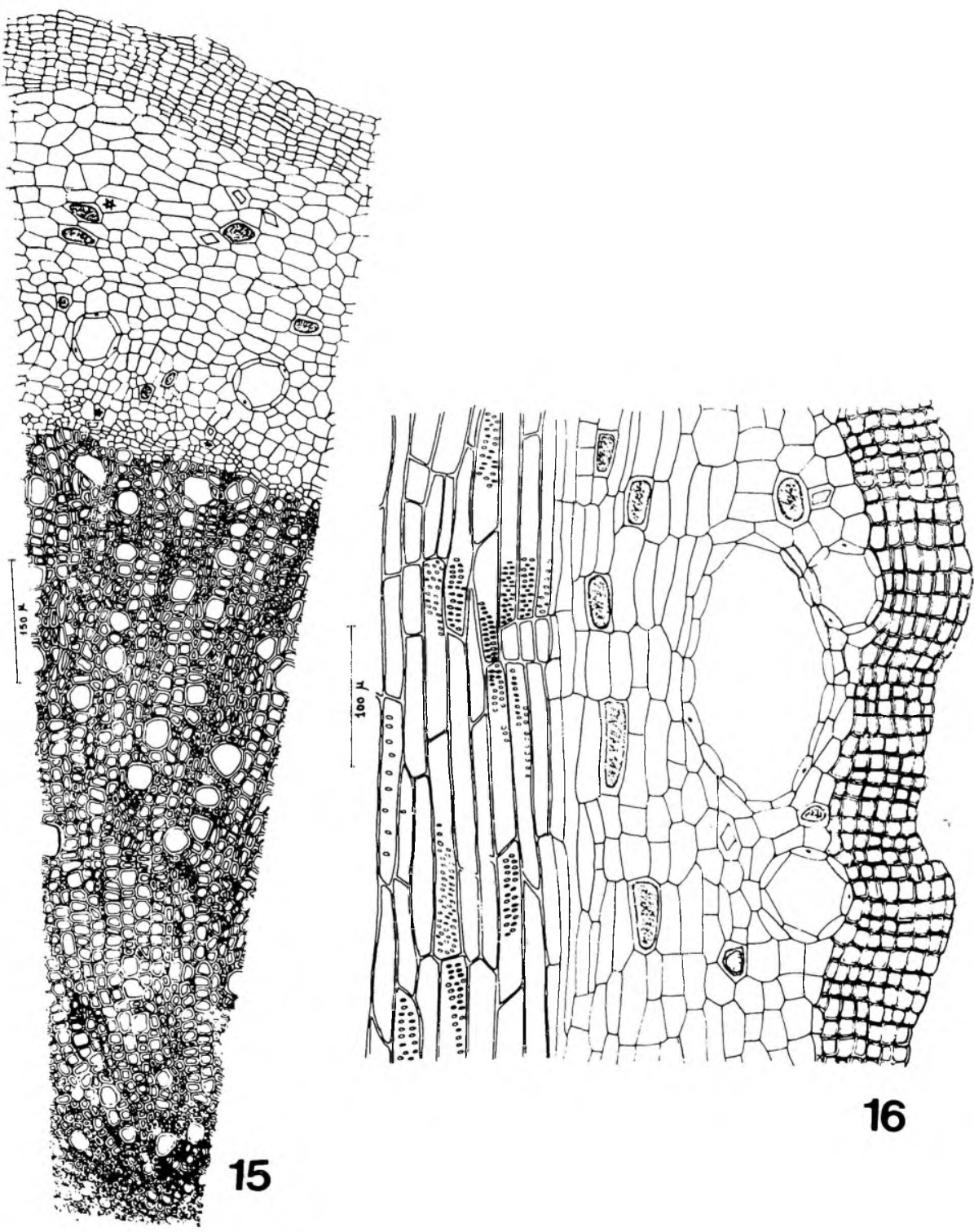

Fig. 15 - Aspecto geral da estrutura secundária da raiz.

Fig. 16 - Detalhe anatômico da raiz com estrutura secundária, em seção longitudinal. 
algumas fileiras de células dispostas em camadas concêntricas, não apresentando, ainda, cristais e glândulas de óleo essencial, elementos anatômicos característicos dessa planta. A epiderme, com suas características próprias, mostra freqüentes pelos unicelulares.

Numa raiz, já com a estrutura secundária (Figs. 15 e 16), notase, inicialmente, a atividade cambial que vai formar os elementos histológicos que vão integrar os sistemas axial e radial, estando este último representado por raios vasculares unisseriados e bisseriados. Os vasos de xilema são do tipo pontuado cujas pontuações mostram a abertura alongada transversalmente; o floema secundário é ainda reduzido. Acompanhando os elementos de condução, há fibras irregularmente distribuidas.

Após o câmbio adquirir contorno circular, os tecidos vasculares secundários tomam a forma de um cilindro contínuo, envolvendo o xilema primário (Figs. 13 e 14). O periciclo apresenta agora divisões periclinais, preparatórias para a formação do felogênio (Fig. 13). Este tem origem na camada mais externa do periciclo em divisão. O felogênio, entrando em atividade meristemática, vai formar uma periderme, cujo súber consta de algumas camadas de células dispostas radialmente.

$\mathrm{Na}$ zona cortical foram observadas modificações histológicas, destacando-se a presença de cristais e glândulas de óleo essencial com contorno circular, delimitadas por uma camada de células secretoras.

Numa fase mais adiantada do desenvolvimento da raiz, o parênquima cortical torna-se amassado, suas células apresentam-se espessadas, acumulando conteúdo amorfo que não se cora pela solução de cloreto férrico a 1\%. O aumento do cilindro vascular vai determinar ruptura e, posteriormente, desprendimento dos tecidos que se encontram para fora da periderme.

\section{$2.3 .2-$ Caule}

Como na raiz, foi feito inicialmente um estudo anatômico do caule ainda novo (Fig. 17), verificando-se que no caule, ainda jovem, os feixes vasculares estão separados, uns dos outros, por estreitos raios medulares de uma a três camadas de células parenquimáticas em largura. O xilema é endarco mostrando os elementos vasculares de protoxilema e metaxilema dispostos em pequenas filas radiais de três a cinco elementos, separados por células parenquimáticas. Em secção 

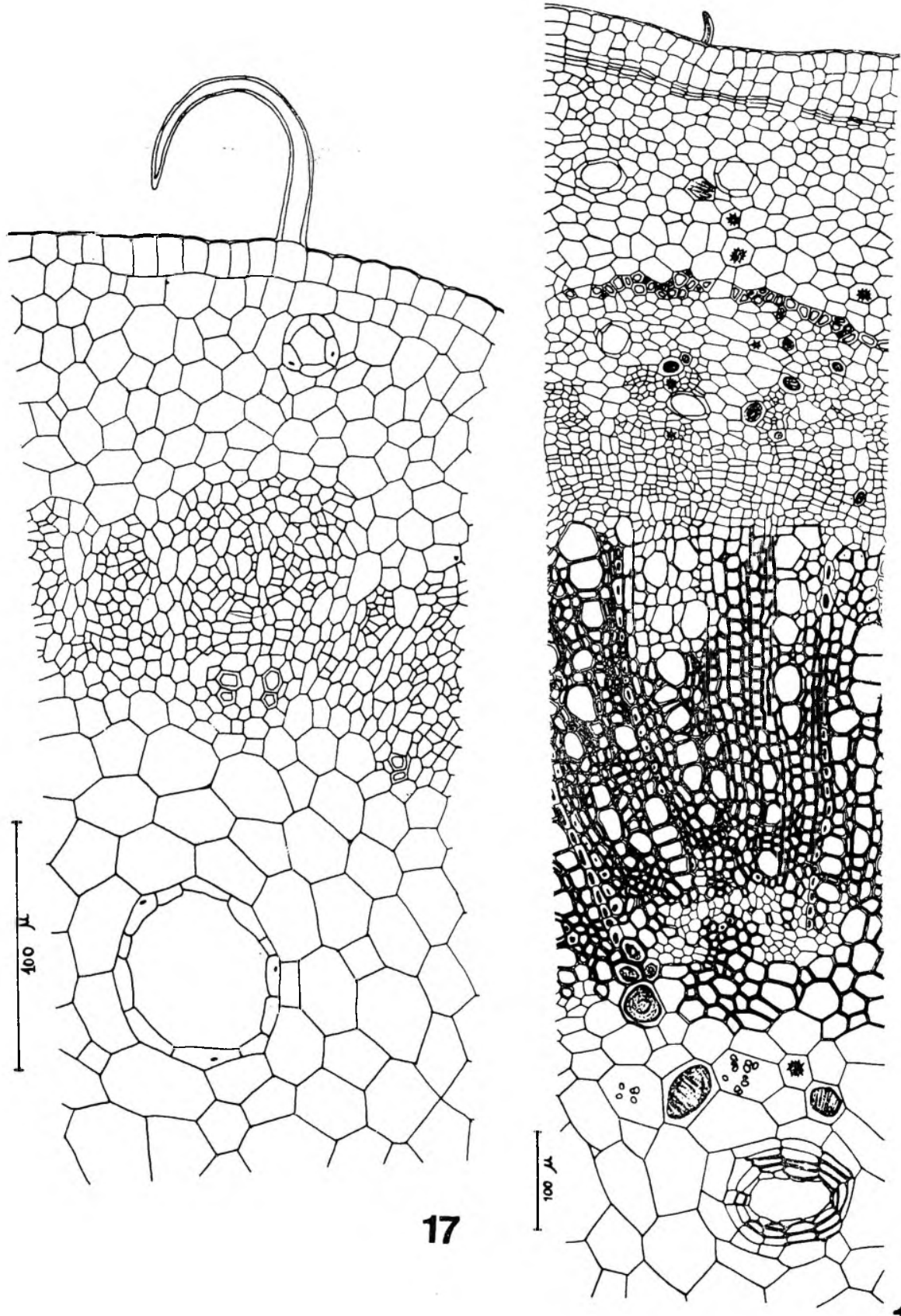

Fig. 17 - Aspecto geral da anatomia do caule com estrutura primária.

Fig. 18 - Aspecto geral da anatomia do caule com estrutura secundária. 
longitudinal, observa-se que o xilema é formado de vasos anelo-espıralados e pontuados. O floema consta principalmente de células parenquimáticas incluindo conteúdo amorfo. Esses elementos histológicos do xilema e floema entram na constituição do sistema axial.

O periciclo é descontínuo e multisseriado, formado por grupos de células, relativamente pequenas, com contorno poligonal e paredes delgadas. Nos parênquimas cortical e medular notam-se freqüentes glândulas de óleo essencial, porém as inclusões cristalinas foram raramente constatadas. O colênquima consta de células pouco espessadas, não deixando espaços intercelulares. A epiderme está provida de cutícula delgada e com freqüentes pelos tectores e estômatos. Os pelos são simples, unicelulares e impregnados por lignina. Os estômatos, geralmente paracíticos (Metcalfe \& Chalk, 1950), estão localizados no mesmo nível das células epidérmicas.

Considerando cortes transversais em série de caule mais desenvolvido (Fig. 18), verifica-se que a atividade cambial ocorre antes do aparecimento do felogênio, passando o câmbio fascicular a formar elementos de xilema e floema secundários. Logo depois, tem origem o câmbio interfascicular que, de início, forma apenas parênquima, aumentando o comprimento dos raios medulares. Em seguida, o anel cambial passa a formar, regularmente, reduzida faixa floemática e um lenho desenvolvido. Os elementos histológicos que entram na formação destes tecidos vasculares estão distribuidos segundo os dois sistemas, axial e radial, intimamente relacionados.

O sistema axial apresenta o xilema secundário formado de numerosas fibras e vasos de diâmetro variado, sendo freqüentes os vasos de grande abertura dispostos em pequenas filas radiais; o floema secundário apresenta o parênquima com freqüentes cristais prismáticos e drusas; as fibras liberianas estão dispostas em pequenos grupos.

O sistema radial é formado por raios vasculares unisseriados e bisseriados cujas células, espessadas por lignina, mostram pontuações simples.

Em secção longitudinal (Fig. 19), observa-se que os elementos vasculares de origem secundária são dos tipos escalariforme e pontuado.

O felogênio tem origem, aproximadamente, a $13 \mathrm{~cm}$ do ápice dos ramos, formando-se logo abaixo da epiderme, numa das primeiras 


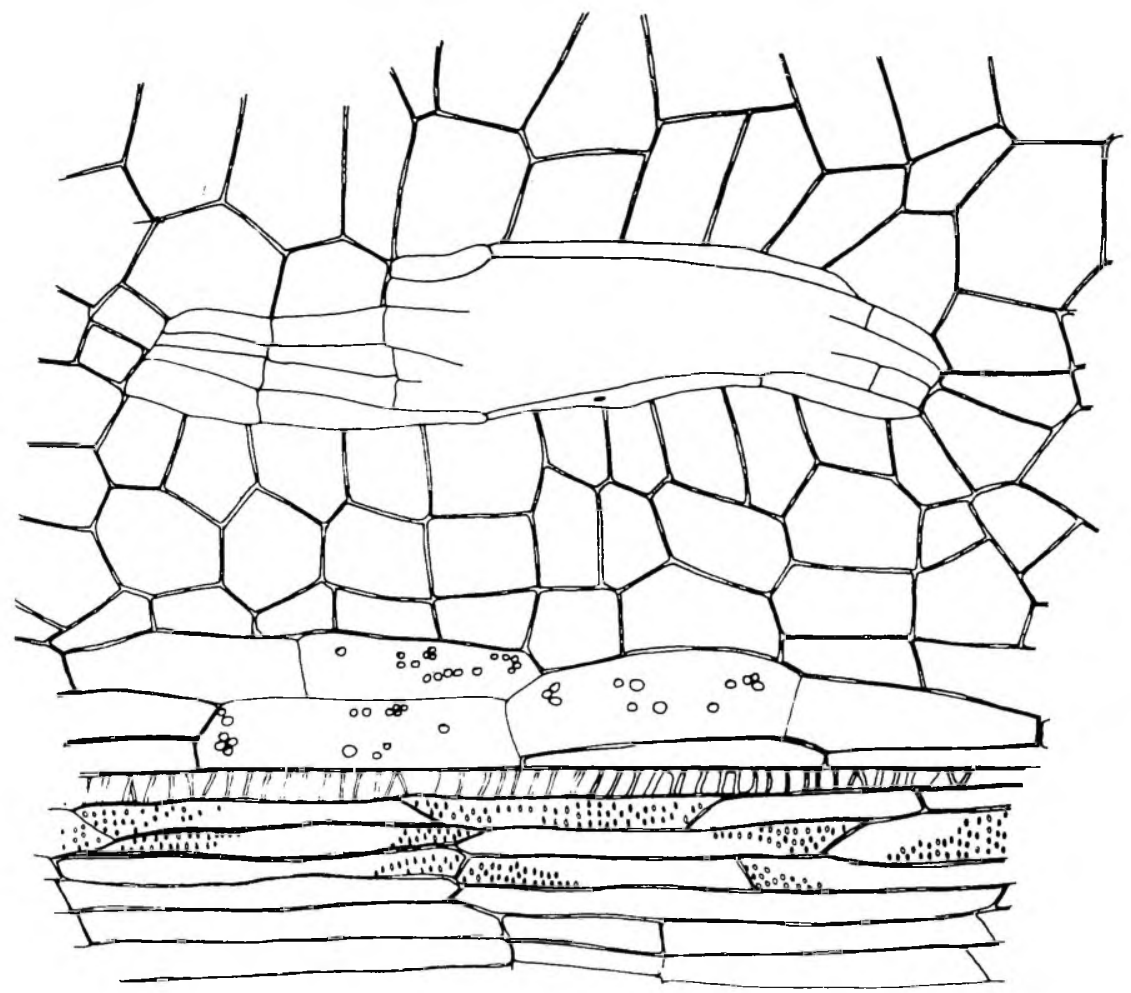

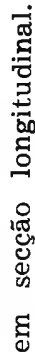

苗

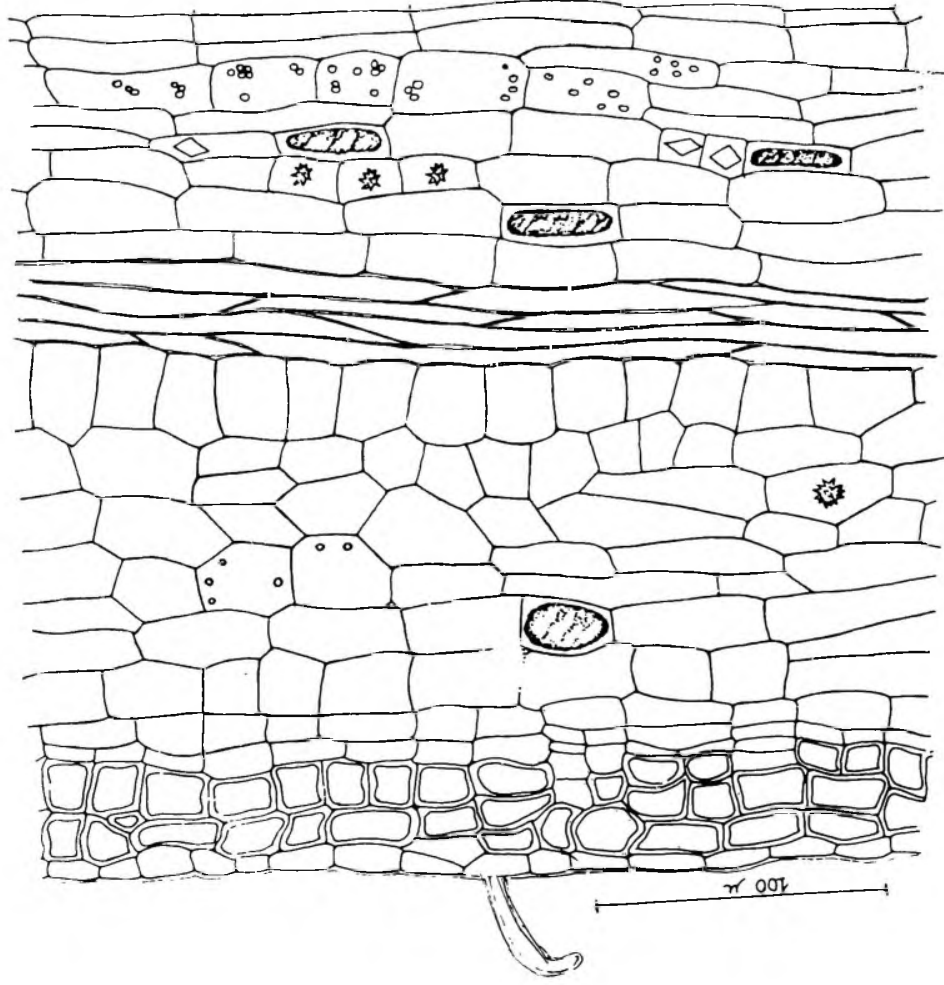

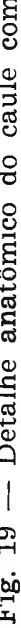



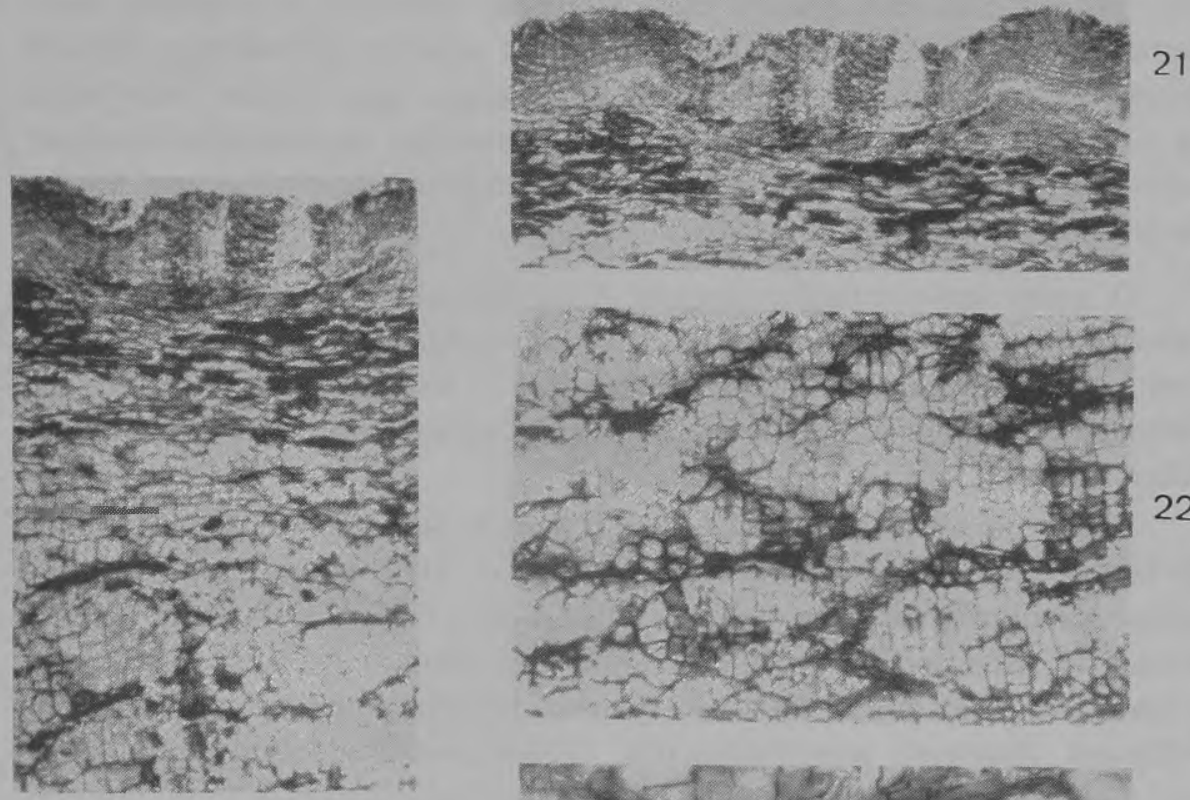

20

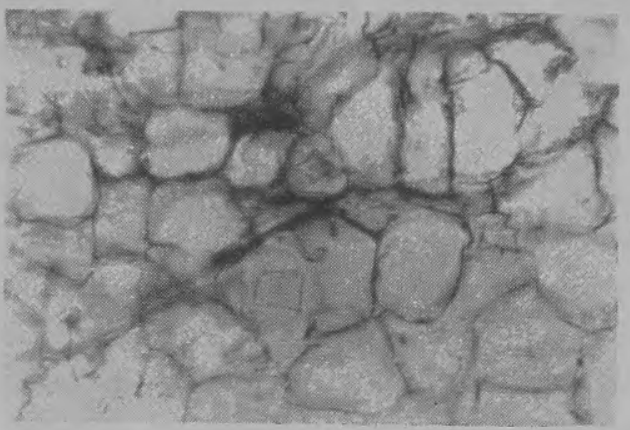

Fig. 20 - Aspecto geral da casca $(50 \times)$.

Fig. 21 - Detalhe da periderme, notando-se lenticelas $(50 \times)$.

Fig. 22 - Detalhe da porção floemática da casca $(50 \times)$.

Fig. 23 - Detalhe do parênquima floemático, notando-se cristais prismáticos $(280 \times)$. 
camadas do colênquima. A atividade felogênica é mais acentuada no sentido de formar súber, estando a feloderma reduzida a poucas camadas de células parenquimáticas dispostas radialmente.

No caule mais desenvolvido, ocorrem algumas modificações histológicas: na epiderme há redução de número de pelos; os cristais prismáticos são mais freqüentes nos tecidos parenquimáticos, onde também são encontradas células com conteúdo amorfo; o periciclo apresenta-se fibroso; o parênquima floemático mostra abundantes cristais prismáticos isolados e sob a forma de drusa; nos tecidos vaseulares há aumento progressivo do número de fibras; no parênquima medular nota-se a presença de canais secretores, melhor observados em secção longitudinal do órgão (Fig. 19).

O lenho apresenta numerosos raios vasculares e anéis de crescimento pouco distintos. Os vasos são encontrados, em média 12 por $\mathrm{mm}^{2}$, predominando os múltiplos de dois a três vasos; associado aos elementos vasculares, há fibras de parede espessa com disposição irregular.

Na casca (Figs. 20 a 23), observa-se a porção floemática constituída por uma larga região de parênquima atravessada por estreitos raios vasculares de uma a duas fileiras de células alongadas. Nessa região da casca, ocorrem muitas células incluindo cristais, sob a forma prismática (Fig. 23) e algumas drusas; pequenos grupos de fibras liberianas, dispostas irregularmente, foram encontrados com freqüência, além de raros escleritos de paredes pouco espessa e com pontuações simples.

O periciclo está constituído por grupos de fibras dispostas irregularmente. O parênquima cortical apresenta-se amassado e com freqüentes cristais prismáticos. A periderme desta casca apresenta um súber constituído de várias camadas de células espessadas principalmente nas paredes laterais e interna; lenticelas são encontradas com frequiência. O feloderma consta de poucas camadas de células parenquimáticas, providas também de cristais prismáticos.

\section{$2.3 .3-$ Folh $\alpha$}

O estudo anatômico foi feito em folhas completamente desenvolvidas, sendo analisada a estrutura do pecíolo e do limbo.

O pecíolo (Fig. 24), em secção transversal ao nivel de sua porção basal, apresenta um feixe vascular colateral. O xilema consta de ele- 


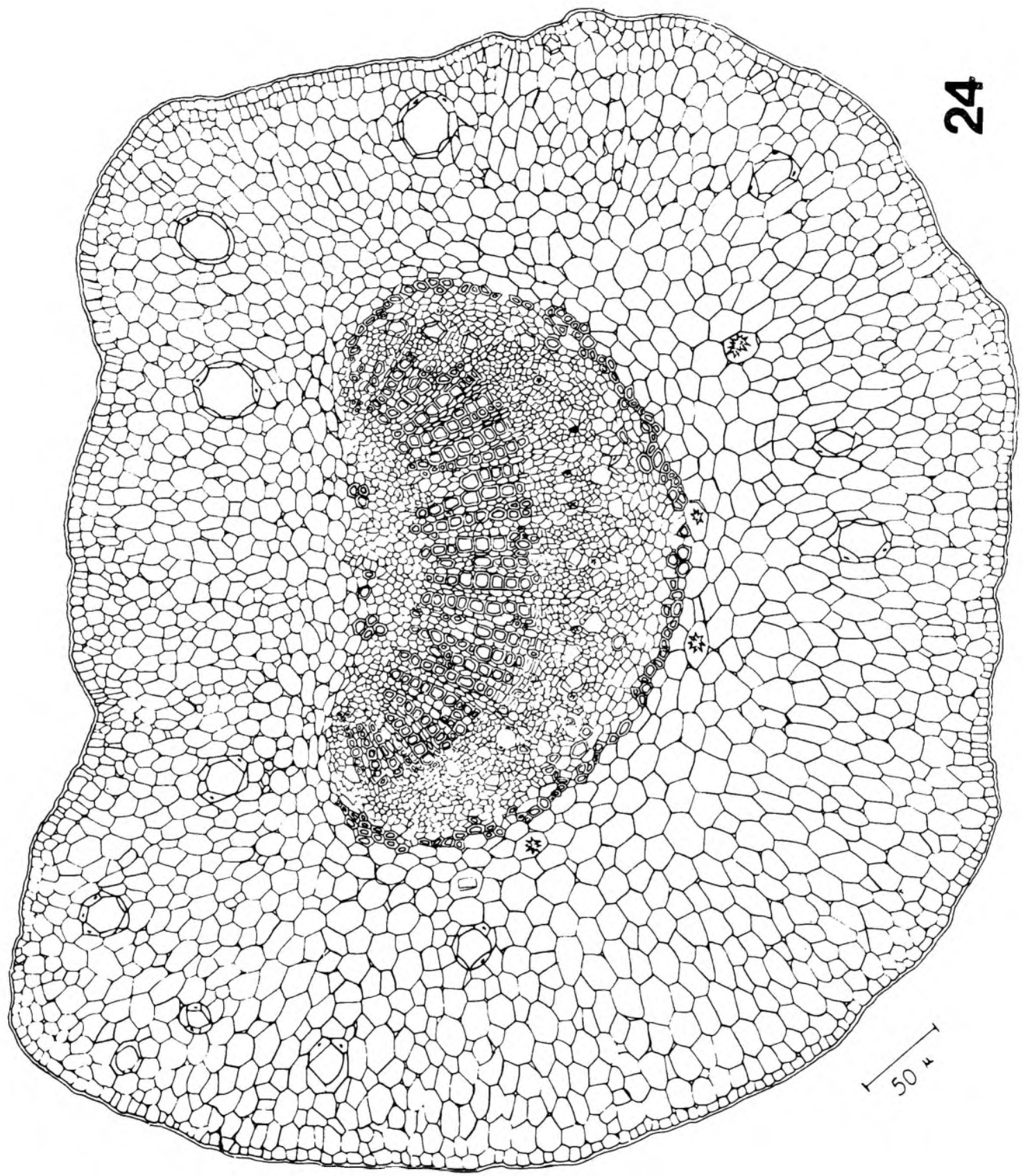

Fig. 24 - Aspecto geral da anatomia do pecíolo, próximo da base. 
mentos vasculares dispostos em pequenas filas radiais de 8 a 10 elementos, separados por células parenquimáticas de paredes espessadas, motrando um conteúdo amorfo de coloração parda escura. No floema notam-se glândulas de óleo essencial, drusas e raros cristais prismáticos. O periciclo é esclerenquimático, sendo contínuo junto do floema e está representado por alguns grupos de fibras próximos do xilema. No parênquima regular, encontram-se freqüentes glândulas, além de drusas, cristais prismáticos e grãos de amilo com tamanho reduzido na camada correspondente à endoderme. A epiderme, provida de cutícula pouco espessa, apresenta estômatos e pelos tectores simples, unicelulares, muitas vezes curvos, impregnados por lignina.

No limbo, foram analisadas: as epidermes, em vista frontal; a nervura mediana, as bordas e a região entre as bordas e a nervura mediana, em secção transversal, ao nível do seu terço inferior.

As epidermes destacadas do limbo, em vista frontal (Figs. 25 e 26), são glabras, constituídas de células com contorno poligonal, de paredes retas na epiderme adaxial (Fig. 25) e levemente curvas na abaxial que é guarnecida de estômatos (Fig. 26) : folha hipostomática (Esau, 1965). Os estômatos estão distribuídos irregularmente, predominando o tipo paracítico. As células epidérmicas apresentam paredes verticais pouco espessas e com delicadas pontuações simples.

A Região da nervura mediana, em secção transversal (Figs. 30 e 31), mostra constituição histológica semelhante à do pecíolo, onde foram também encontradas as mesmas inclusões. Na nervura, porém, foi observado uma camada endodérmica com espessamento de lignina nas paredes internas e radiais.

A região das bordas (Fig. 27) está constituída por uma epiderme provida de cutícula espessa, revestindo um colênquima e um parênquima regular clorofilado. Neste parênquima, notam-se um feixe vascular, glândulas de óleo essencial e drusas.

A região entre a nervura e as bordas (Fig. 28) apresenta as duas epidermes revestindo um mesofilo heterogêneo e assimétrico. O parênquima paliçádico consta de dois estratos celulares, sendo a primeira camada formada de células cilíndricas e regularmente dispostas em paliçada; a segunda camada é formada de células relativamente mais curtas, sem apresentar aquela disposição característica. O parênquima esponjoso ocupa, proporcionalmente, mais da metade do mesofilo, sendo formado de células irregulares na forma e no tamanho. No mesofilo 

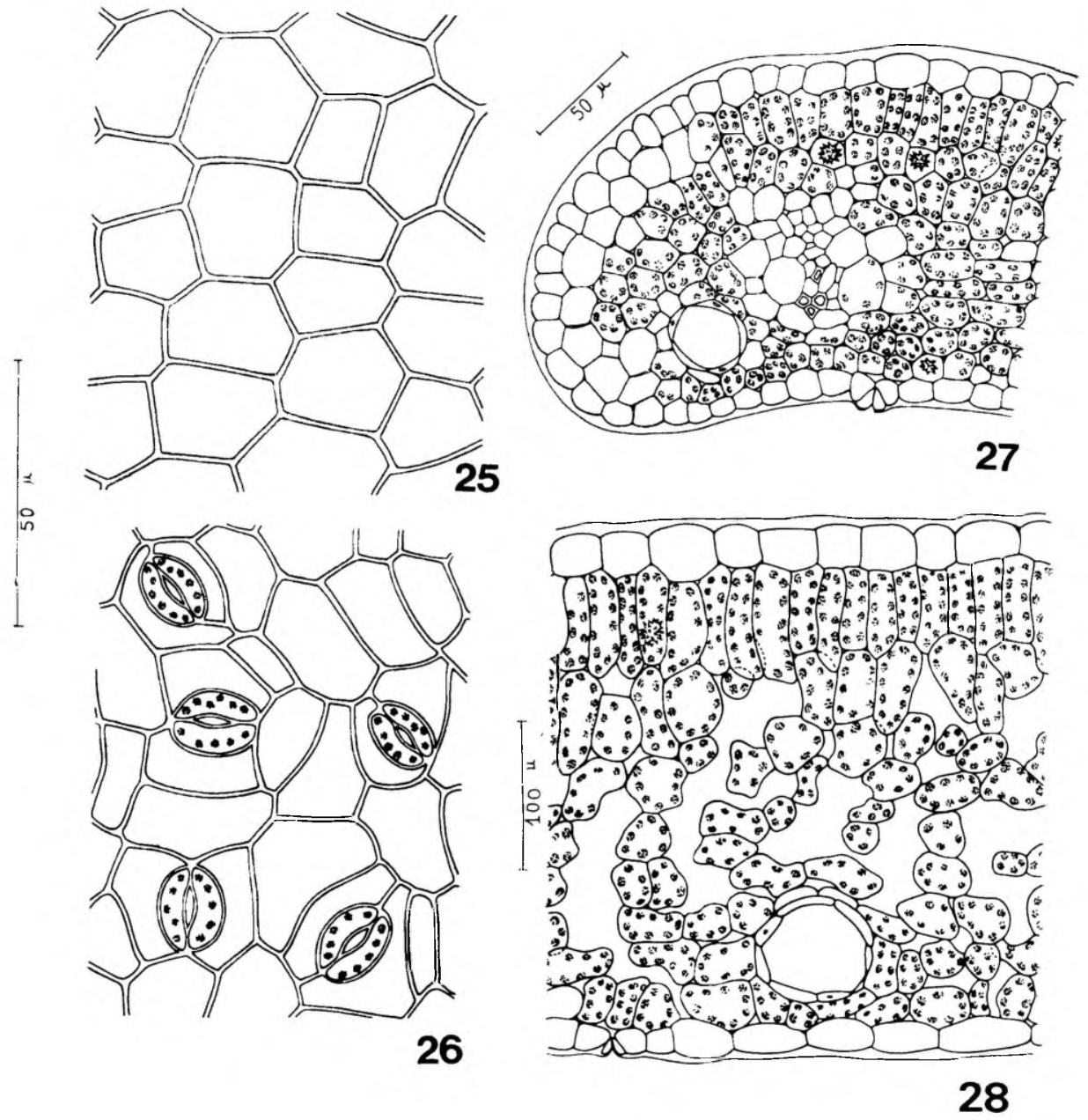

Fig. 25 - Epiderme adaxial, em vista frontal.

Fig. 26 - Epiderme abaxial, em vist afrontal, mostrando estômatos paracíticos. Fig. 27 - Aspecto anatômico da folha, na região da borda.

Fig. 28 - Aspecto anatômico da folha, na região entre a borda e a nervura mediana. 
notam-se pequenos feixes vasculares cada qual envolvido por uma bainha de células parenquimáticas, drusas e glândulas. Considerando cortes seriados em folhas jovens, foi possível constatar a origem esquizógena destas glândulas, baseando-se em alguns estágios de seu desenvolvimento (Fig. 29). Um exame microscópico minucioso revelou a presença de células glandulares em divisão, seguindo-se a formação da lacuna esquizógena, limitada externamente por um estrato de células secretoras que se tornam achatadas.

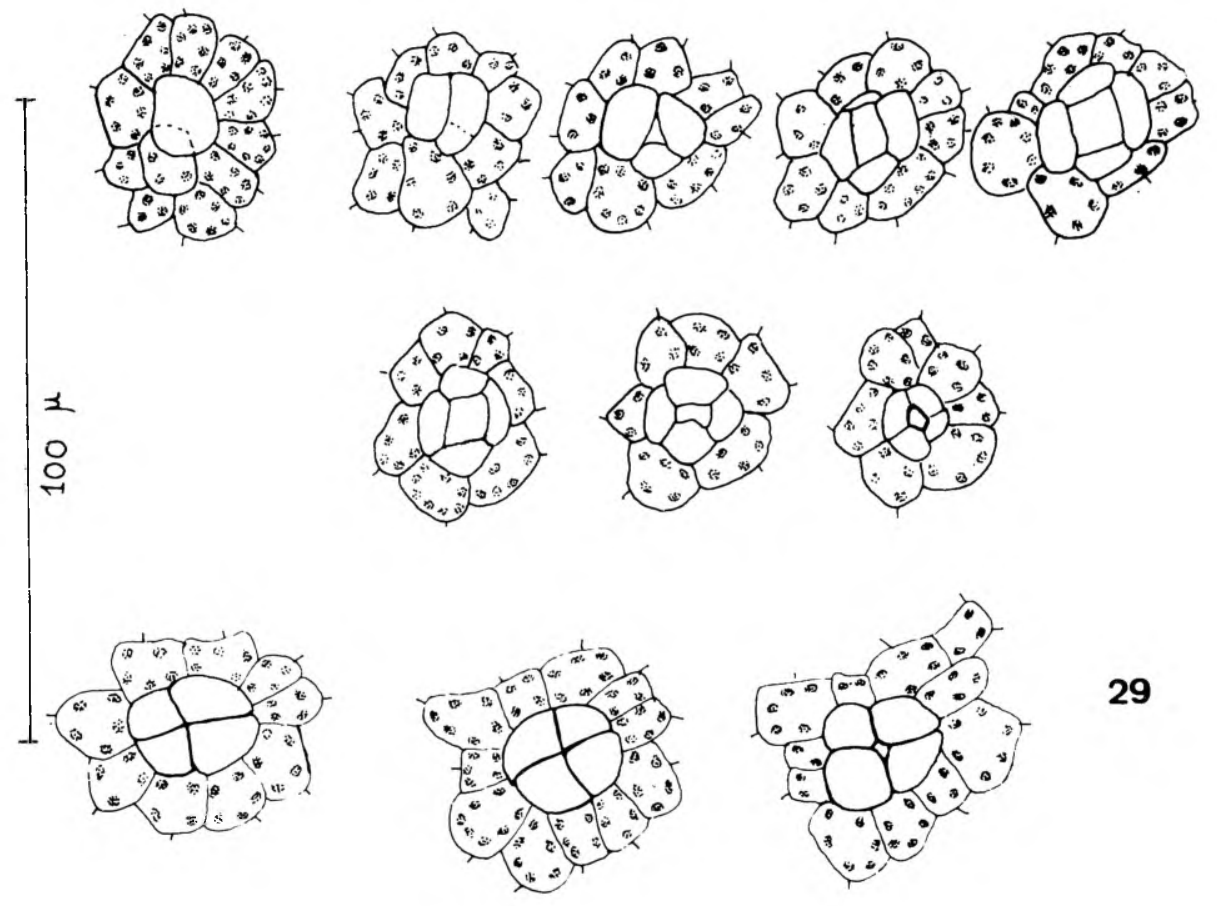

Fig. 29 - Alguns estágios de desenvolvimento da glândula de óleo essencial, mostrando sua origem esquisógena.

\section{$2.3 .4-F l o r$}

O estudo anatômico da flor foi feito analisando a estrutura dos verticilos florais em secção transversal.

O verticilo protetor de uma flor adulta (Fig. 32) apresenta as sépalas formadas de duas epidermes revestindo uma região parenquimática com delicados feixes vasculares. O parênquima é regular, cloro- 

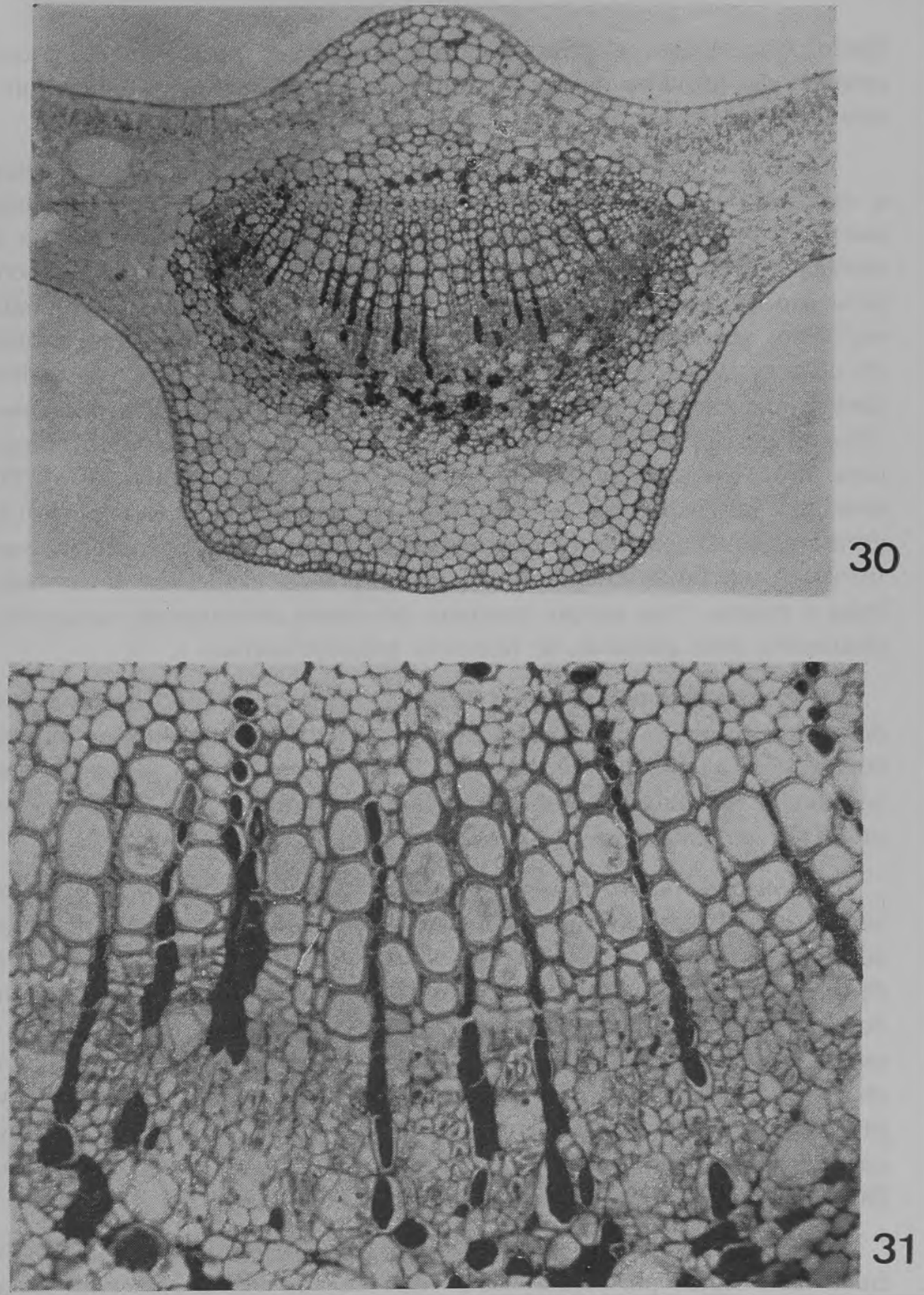

Fig. 30 - Aspecto anatômico da folha, na região da nervura mediana $(60 x)$.

Fig. 31 - Detalhe do feixe vascular da nervura mediana, notando-se as glândulas de óleo essencial no floema e células com conteúdo pardo-escuro no parênquima $(250 \times)$. 
filado, com drusas e glândulas. As epidermes, com cutícula pouco espessa, são providas de raros estômatos e pelos tectores simples, unicelulares, relativamente longos, impregnados de lignina.

O androceu consta de estames cuja antera adulta (Fig. 33) mostra a epiderme provida de cutícula delgada com protusões. A camada mecânica é formada de células alongadas, diminuindo de tamanho à medida que se aproximam da linha de deiscência; estrias higroscópicas são nitidamente observadas nas células dessa camada. A camada nutritiva, quando encontrada na antera adulta, está reduzida a uma ou duas camadas de células alongadas transversalmente e com protoplasma picnótico. Nessa antera verifica-se, em cada teca, o desaparecimento parcial da parede divisória dos dois sacos polínicos, formando uma loja. No interior das lojas, notam-se grãos de pólen (Fig. 33) isolados, esféricos, com exina granulosa apresentando três poros de germinação. O conectivo é constituido de um parênquima regular, contornando um feixe vascular formado de poucos elementos de protoxilema e floema. Na porção mediana da antera encontra-se, caracteristicamente, uma glândula de natureza parenquimática.

O filete apresenta uma estrutura simples, constando de uma epiderme ligeiramente cutinizada, com pelos tectores unicelulares longos, envolvendo um parênquima regular, tendo no centro um pequeno feixe vascular. No androceu notam-se, ainda, os estaminódios que têm uma estrutura semelhante a do filete.

O gineceu mostra a parede ovariana (Fig. 34), em secção transversal, constituída de duas epidermes com cutícula delgada, providas de raros estômatos e pelos tectores unicelulares; entre as epidermes, distingue-se um parênquima regular onde foram observadas as glândulas de óleo essencial e feixes vasculares nas regiões das nervuras e nas zonas de união das bordas das folhas carpelares. Analisando a estrutura desses feixes, dependendo do nivel observado, verifica-se uma inversão na posição do floema em relação ao xilema. Internamnte, na região das bordas dos carpelos, notam-se as placentas, de natureza parenquimática, onde inserem os óvulos que são do tipo anátropo.

O estilete consta de uma epiderme, com cutícula delgada, revestindo uma região parenquimática. Em relação com a epiderme, notase um parênquima regular de células relativamente grandes, com glândulas e três pequenos feixes vasculares, cada qual correspondendo a uma folha carpelar. Internamente, ocupando a porção central da estru- 

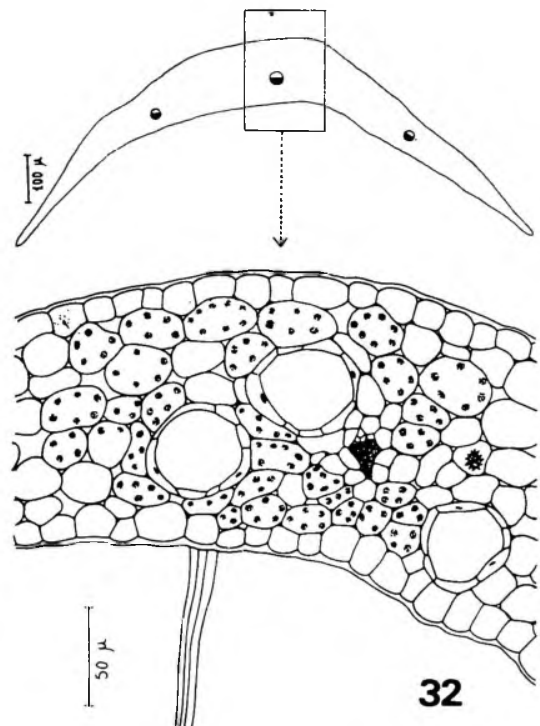

1.
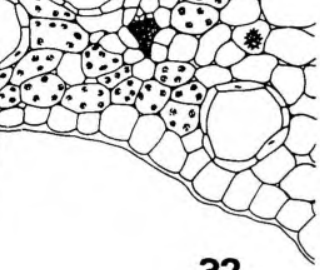

32
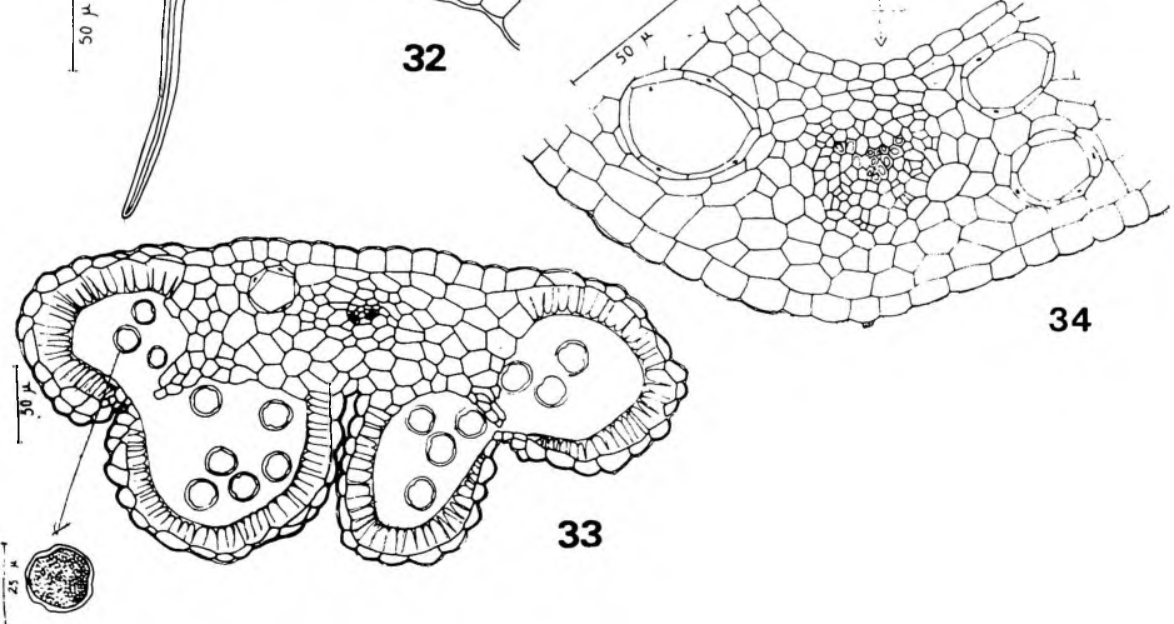

34

Fig. 32 - Aspecto anatômico da sépala, na sua região mediana, notando-se o detalhe de um pelo tector.

Fig. 33 - Aspecto anatômico da antera, observando-se as estrias higroscópicas na camada mecânica e detalhe de um grão de pólen.

Fig. 34 - Detalhe anatômico de uma região da paređe ovariana, notando-se a inversão da posição do floema em relação ao xilema. 
tura, observa-se o parênquima estigmóide (Esau, 1965) fistuloso, constituído de células pequenas, sem deixar espaços intercelulares.

O estigma apresenta uma epiderme com numerosas papilas, observando-se abaixo desta, em secção transversal, um tecido parenquimático denso.

\section{$2.3 .5-$ Fruto}

O estudo anatômico do fruto, em secção transversal ao nivel de sua porção mediana, foi feito analisando as modificações histológicas da parede ovariana para constituir o pericarpo (Figs. 35 a 37).

As epidermes do ovário sofrem divisões periclinais, antes de diferenciarem-se no epicarpo e endocarpo, onde não mais são observados os pelos e estômatos. O epicarpo é formado de duas a três camadas de células, dispostas transversalmente, cujas paredes são ligeiramente espessadas. O endocarpo consta de várias camadas de células que apresentam modificações acentuadas tornando-se, com freqüência, fibrosas e lignificadas na fase final de desenvolvimento do fruto.

A região parenquimática da parede ovariana apresenta modificações histológicas para constituir o mesocarpo, cujas células se tornam irregulares na forma e no tamanho, apresentando um processo progressivo de lignificação nas regiões correspondentes à deiscência do fruto (Fig. 36). No mesocarpo diferenciam-se alguns escleritos; cristais prismáticos e drusas são encontrados com freqüência (Fig. 37); as glândulas de óleo essencial tornam-se alongadas transversalmente (Fig. 36).

\section{3 .6 - Semente}

As sementes (Figs. 35, 38 e 39) são originadas de óvulos anátropos e, quando maduras, apresentam a seguinte estrutura: tegumento seminal, formado de duas camadas de células, sendo que a camada externa, relacionada com o arilo, consta de células com paredes alongadas no sentido transversal; internamente, há uma camada de células grandes com contorno quadrangular mostrando espessamento de lignina nas paredes radiais e interna, onde se notam numerosas estrias e pontuações simples. O endosperma é desenvolvido, constando de um parênquima formado de células com contorno poligonal, paredes delgadas incluindo grãos de aleurona em abundância (Figs. 38 e 39) ; envolvendo 

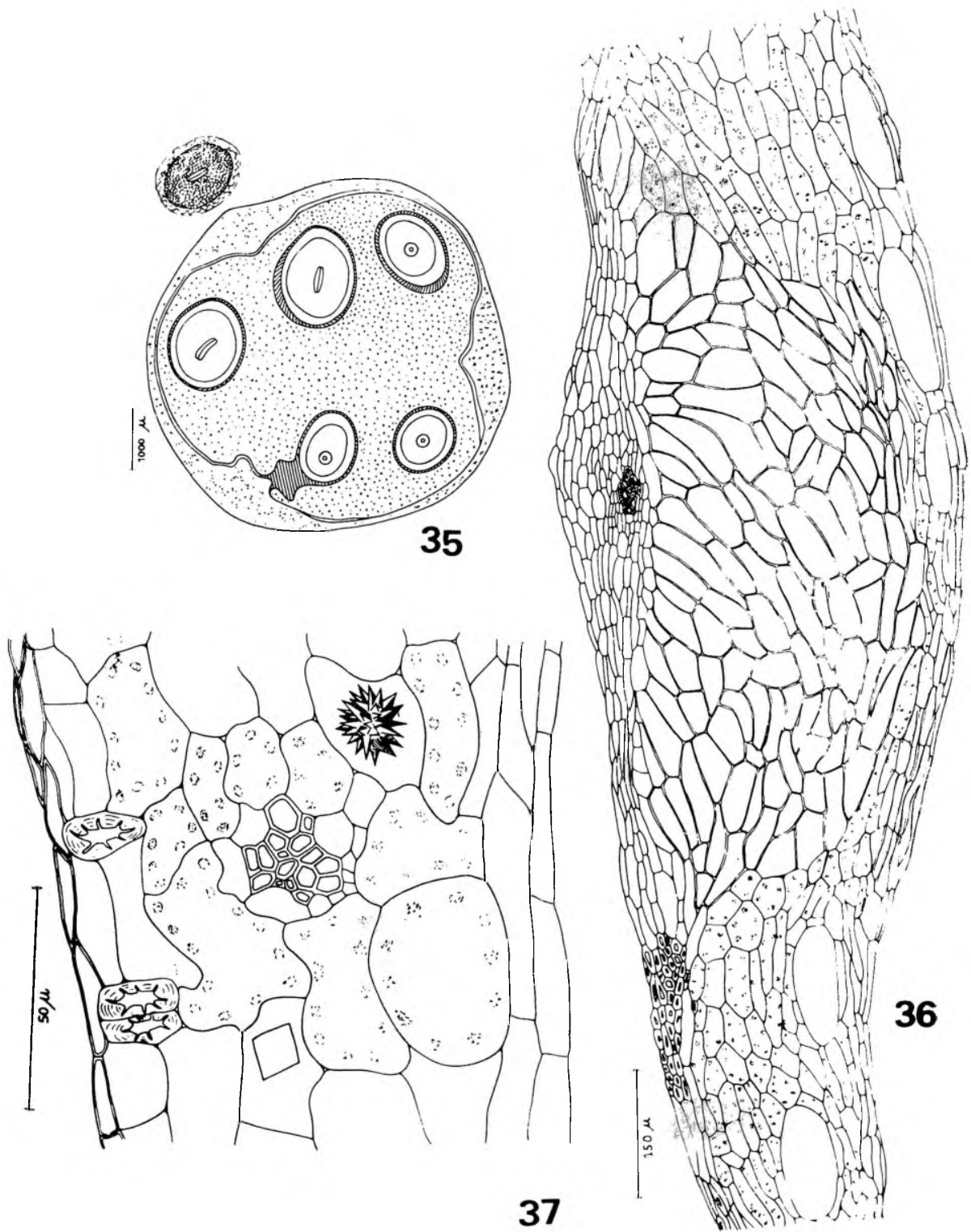

Fig. 35 - Aspecto diagramático do fruto, em secção transversal, mostrando o pericarpo e as sementes envolvidas pelo arilo.

Fig. 36 - Detalhe anatômico da parede do fruto, no qual se nota a região da deiscência onde as células são lignificadas.

Fig. 37 - Detalhe anatômico da parede do fruto, na região entre as zonas de deiscência. 


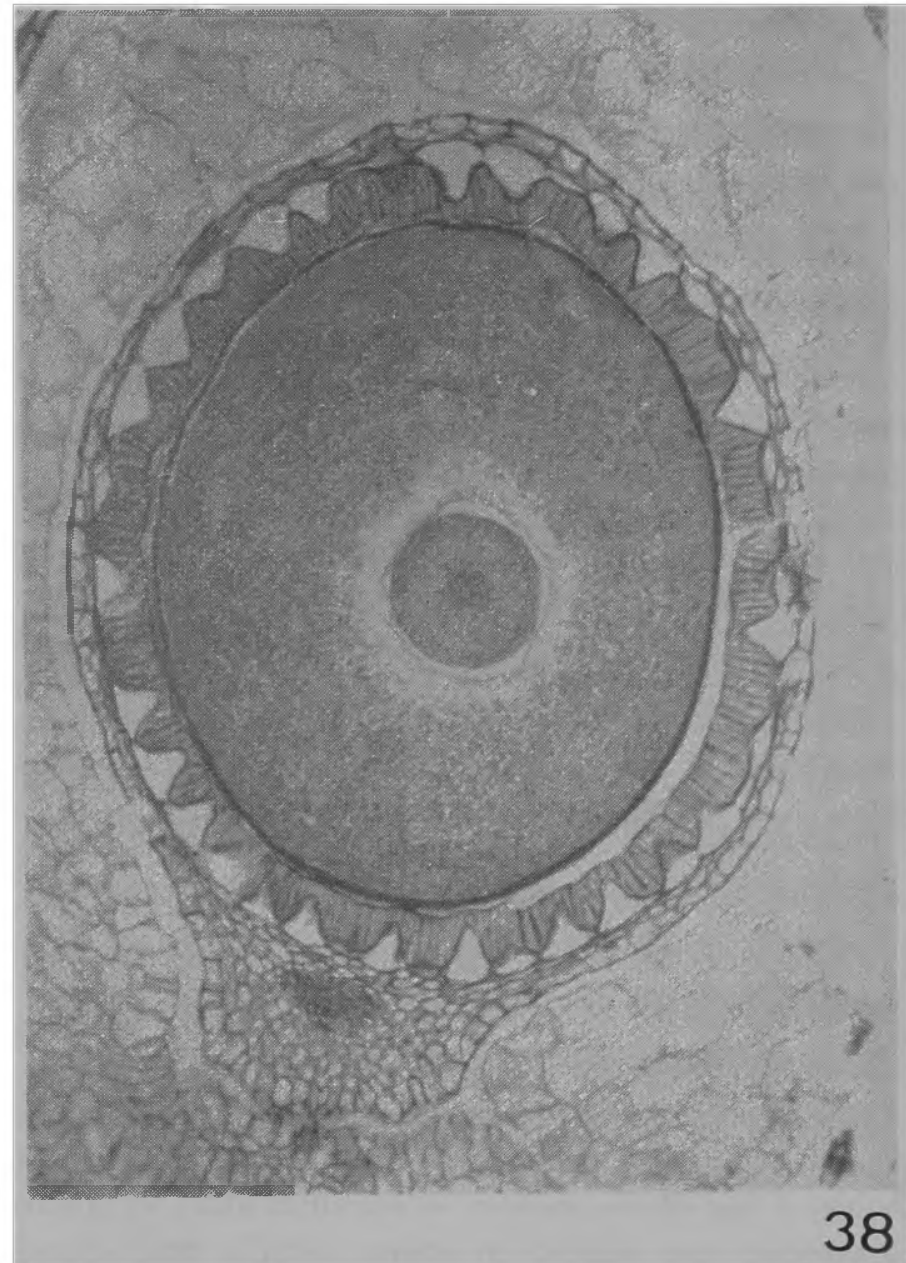

Fig. 38 - Aspecto geral da anatomia da semente, envolvida pelo arilo, notando-se ainda ,o espessamento de lignina no tegumento protetor $(45 \times)$. 
o endosperma, há uma camada de célula alongadas transversalmente, com conteúdo amorfo de coloração parda. O embrião apresenta os cotilédones pouco desenvolvidos, de natureza parenquimática.

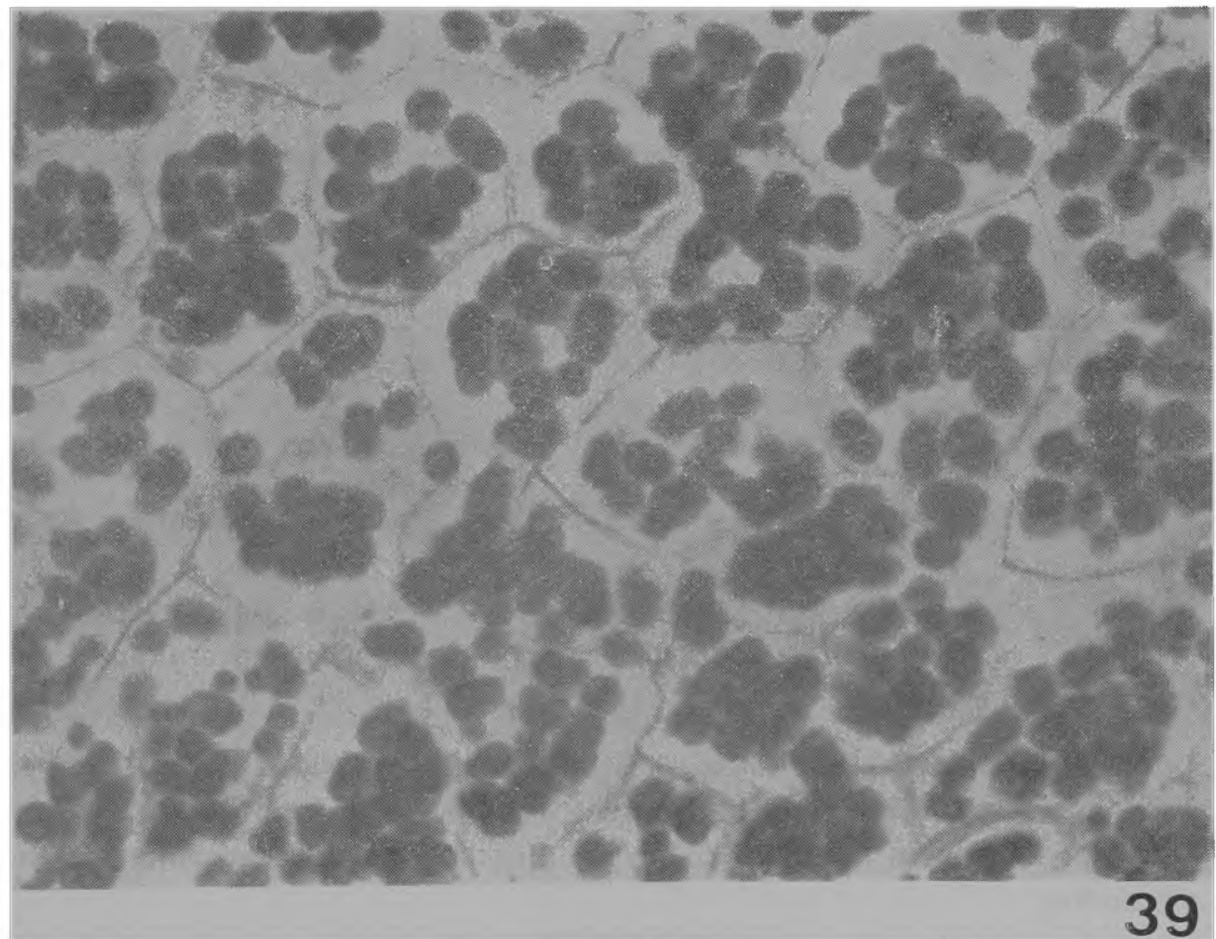

Fig. 39 - Detalhe anatômico da semente, mostrando uma região do endosperma com grãos de aleurona $(470 \times)$.

\section{3 - ENSAIOS QUİMICOS}

\section{1 - Material e Método}

As amostras de folha foram coletadas, em setembro de 1971, nos lugares já mencionados e após secagem, à temperatura ambiente, foram transferidas para uma estufa de $60^{\circ}$, permanecendo aí 30 minutos. Em seguida, foram obtidos extratos de acordo com a técnica farmacognóstica. No caso particular dos óleos essenciais, a extração foi feita, por destilação em corrente de vapor, a partir de folhas após secagem à temperatura ambiente. 


\section{2 - Parte Experimental}

Estes ensaios foram efetuados para a verificação dos seguintes princípios ativos:

3.2.1 - Alcalóides - Uma fração de droga (1 g) foi homogeneizada com 3 gotas de hidróxido de amônio e, depois, tratada pelo clorofórmio. O solvente foi eliminado e o resíduo tratado com $0,5 \mathrm{ml}$ de ácido clorídrico a $1 \%$.

Através de passagens sucessivas em meio ácido e alcalino, chegou-se a uma terceira purificação, procedendo-se, em seguida, algumas reações gerais de precipitação de alcalóides. Na solução clorídrica a $1 \%$, executadas as reações com os reagentes de Mayer, Dragendorff, Bouchardat e ácido pícrico a $1 \%$, não se verificou a formação de precipitado.

3.2.2 - Saponinas - Foi preparado um extrato aquoso da droga a $10 \%$ a fim de efetuar-se o ensaio do seu poder espumante. Após aquecimento, o extrato aquoso foi esfriado e filtrado. Agitou-se a solução no sentido longitudinal, notando-se a formação de espuma persistente. Este ensaio foi negativo para concentrações menores do extrato aquoso.

3.2.3 - Antraderivados - Efetuou-se a reação de Borntraeger, baseando-se na Farmacopéia Brasileira (1959), e não se observou, na camada amoniacal com hidróxido de amônio, a coloração amarela ou vermelha.

3.2.4 - Cumarinas - Preparou-se um extrato aquoso da droga a $1 \%$ que foi, em seguida, esfriado e filtrado. Transferiram-se $5 \mathrm{ml}$ dessa solução para um tubo de ensaio e, observando-se à luz ultravioleta, não se verificou fluorescência azul. Na solução, alcalinizada e novamente exposta à luz ultravioleta, não se verificou a coloração verde-azulada.

3.2.5 - Taninos - A droga não apresenta sabor adstringente, mas, assim mesmo, foram efetuadas algumas reações para taninos. No extrato aquoso, adicionado de gotas de solução a $1 \%$ dos seguintes reagentes: cloreto férrico, acetato de cobre, ágtua bromada, gelatina e sulfato de ferro amoniacal, não se verificou resultado positivo.

3.2.6 - Derivados flavonóides - Uma fração da droga (1 g) foi extraída com $10 \mathrm{ml}$ de álcool etílico a $80 \%$, aquecendo-se até ebulição. 
A seguir, filtrado o extrato e eliminado o solvente por evaporação, o resíduo foi resuspenso em água destilada, sendo os derivados flavonóides presentes na solução aquosa extraídos com éter etílico. O solvente foi eliminado em banho-maria e o resíduo resuspenso em álcool etílico. Neste extrato foi verificada a fluorescência à luz de Wood e, a seguir, procedeu-se a análise cromatográfica empregando-se os reveladores indicados por Stahl (1969). Nestas condições foram observadas manchas fluorescentes.

3.2.7 - Óleo essencial — A observação anatômica de glândulas secretoras já indica a presença desse princípio, no entanto, foram executadas a extração, caracterização e análise cromatográfica do óleo essencial obtido da folha.

3.2.7.1 - Extração - Para a extração do óleo foram usadas folhas secas, à temperatura ambiente, pulverizadas, distilando-se em corrente de vapor, no aparelho de Clevenger, modificado por Wasicky (1963). Após a destilação, obteve-se um rendimento de 2,1\% de óleo essencial que se apresentou sob a forma de um líquido amarelado, com odor semelhante ao do cedro e sabor não característico. Em seguida, efetuou-se uma análise cromatográfica em camada delgada que demonstrou, aparentemente, a presença de nove manchas distintas. Depois, procedeu-se uma análise cromatográfica em fase gasosa desse óleo essencial, mas, em ambos os casos, por falta de padrões, não foi possivel identificar, ainda, a natureza química de seus componentes.

\section{4 - DISCUSSÃO}

O material botânico, coletado nas imediações da Cidade Universitária "Armando Salles de Oliveira", São Paulo, Capital, foi morfologicamente identificado por comparação, correspondendo à descrição que se encontra na obra de Martius (1841/1872).

O fato de ser esta Casearia, vulgarmente, conhecida por "cafébravo" ou "café-do-diabo" induz-nos a crer que é tóxica, mas as observações feitas por Hoehne (1939), não confirmaram sua toxidez para os animais.

A ampla distribuição desta espécie na América Tropical, especialmente no Brasil, justifica, de certo modo, a existência de muitos nomes vulgares, assim como a preferência em seu uso popular. 
A C. sylvestris Swartz está incluida na Farmacopéia Brasileira (Silva, 1929), onde a droga está representada pela folha. Além desse órgão, há também indicação da raiz segundo Freise (1934) e Hoehne (1941), mas a folha é a parte da planta, economicamente mais interessante. Após a revisão da Farmacopéia Brasileira, essa droga passou para o Formulário Nacional, apesar de suas aplicações, particularmente em medicina popular.

Considerando a anatomia do axófito, raiz e caule, foi feito um estudo comparativo entre as estruturas jovens e adultas, analisando as modificações histológicas desses órgãos. Inicialmente, verificou-se no procâmbio da raiz dois polos de diferenciação xilemática, constituindo uma estrutura diarca característica dessa planta. O número de polos do protoxilema costuma ser maior na base de uma raiz, mas, observando-se cortes seriados desse órgão, verificou-se a persistência da estrutura diarca. A raiz mostra, portanto, de acordo com a teoria estelar, estrutura protostélica, radiada e diarca.

Metcalfe \& Chalk (1950), tratando da anatomia de caule de plantas pertencentes às Flacourtiaceae, afirmam que os feixes vasculares, na maioria dos gêneros examinados, formam um cilindro vascular contínuo separados por estreitos raios medulares. Esta estrutura dissecada, associada à presença de medula, também foi observada em $C a$ searia, permitindo classificá-la como sifonostélica dissecada ectoflóica.

O axófito apresenta, como característica histológica marcante, a presença de glândulas de óleo essencial e cristais.

Os autores, acima referidos, considerando a anatomia da família, dizem que não há particularidades notáveis, mas que a freqüência e a distribuição dos cristais nos tecidos auxiliam na identificação do gênero e das espécies. No caso da $C$. sylvestris Swartz nota-se no axófito, principalmente com estrutura secundária, a presença de abundantes drusas e cristais prismáticos, sendo estes mais freqüentes na casca; canais secretores foram observados na região da medula, particularidade esta não referida na literatura consultada.

Com relação à folha dessa planta, há algumas referências anatômicas e fitoquímicas porque é a parte da planta geralmente utilizada em terapêutica. Neste órgão também foram observadas as glândulas de óleo essencial e inclusões cristalinas, principalmente sob a forma de drusa. Na Farmacopéia Brasileira (Silva, 1926), não há referência sobre inclusões de cristais que constituem uma característica anatô- 
mica da planta estudada. Metcalfe \& Chalk (1950) citam, em $C a$ searia, a ocorrência de freqüentes cristais em diversos tecidos; afirmam, porém, que muitas espécies desse gênero mostram, caracteristicamente na epiderme, idoblastos com cristais, fato este não constatado por nós na $C$. sylvestris Swartz. Estes autores, referindo-se ainda ao estudo anatômico da folha, afirmam a ocorrência de estômatos nas duas epidermes do tipo paracítico. Em nossas observações, porém, foram observados estômatos somente na epiderme abaxial, predominando o tipo acima referido.

Baseando-se em alguns estágios de desenvolvimento na folha jovem, foi possível demonstrar a origem esquizógena das glândulas de óleo essencial, descritas por Gilg (1925) como glândulas de resina.

$\mathrm{Na}$ literatura compulsada, não há citações sobre a anatomia dos órgãos reprodutores e poucas são as referências com relação ao estudo fitoquímico da $C$. sylvestris Swartz.

Possolo \& Ferreira (1949) verificaram na folha a presença de óleo etéreo, saponinas e alcalóides. Entretanto, em material coletado na Cidade Universitária, em São Paulo, baseando-se nos ensaios químicos, não constatamos a presença de alcalóides. A explicação dessa controvérsia pode ser esclarecida analisando as condições em que foram feitos os ensaios químicos, assim como o local, a época em que foi coletado e, possivelmente, a presença de variedades bioquímicas distintas. Os autores citados utilizaram, em suas observações, reações de coloração para alcalóides, quanđo a prática demonstra melhores resultados com as reações de precipitação. No que se refere às saponinas, a sua indicação só foi possível em extratos muito concentrados.

Com relação ao óleo essencial extraido de folhas secas e após destilação em corrente de vapor no aparelho de Clevenger, modificado por Wasicky (1963), foi obtido um rendimento de 2,1\%, em relação à droga seca, teor ligeiramente inferior ao referido por Possolo \& Ferreira (1949) que conseguiram 2,5\% nas mesmas condições. Brasil e Silva \& Bauer (1970), analisando o óleo essencial da folha da C. sylvestris Swartz, coletado em certas regiões do Rio Grande do Sul, constataram elevada porcentagem de terpenos $(77,78 \%)$ e ácido hexanóico $(0,58 \%)$.

Claus \& Tyler (1928), referindo-se às propriedades medicinais dos óleos essenciais afirmam que muitos deles são antissépticos e as ações 
antimicrobianas e antifúngicas das essência tem sido objeto de uma série de investigações.

A ocorrência do óleo essencial, em porcentagem alta na folha de C. sylvestris Swartz, justificaria de certo modo, algumas de suas indicações terapêuticas.

\section{5 - CONCLUSÕES}

Considerando o estudo feito em $C$. sylvestris Swartz podem ser destacadas às seguintes conclusões:

1 - Nos órgãos vegetativos e de reprodução é constante a presença de glândulas de óleo essencial e inclusões de cristais prismáticos e drusas.

2 - A raiz é protostélica radiada diarca e o caule do tipo sifonostélico dissecado ectoflóico.

3 - A folha apresenta estrutura dorsiventral, sendo hipostomática e com estômatos paracíticos. Neste órgão foi constatado a origem esquizógena das glândulas de óleo essencial.

4 - A folha apresenta alto teor de óleo essencial e indicação da presença de flavonas e saponinas.

\section{REFERÊNCIAS BIBLIOGRĀFICAS}

ABBAyES, H. et col. - Botanique. Saint Germain, Masson et Cie Éditeurs, 1863. p. 778.

ANDRADE, E. N. de - Contribuição para o estudo da flora florestal paulista. São Paulo, Companhia de Estrada de Ferro, 1941. 62 p.

BASU, N. K. \& CHOUDHURY, K. D. - Apud HEGNAUER, R. Chemotaxonomie der Pflanzen. Stuttgart, Birkhäuser Verlag Basel, 1966. v. 4. p. 166.

CAMINHOÁ, J. M. - Compêndio de botânica geral e médica. Rio de Janeiro, Tipografia Nacional, 1877/1884. v. 6. p. 2296-2299.

CLAUS, E. P. \& TYLER, V E. - Farmacognosia. Trad. de Jorge de Coussio. Buenos Aires, El Ateneo, 1968. p. 167.

COIMBRA, R. - Notas de fitoterapia. $2 .^{\mathrm{a}}$ ed. Rio de Janeiro, Lab. Clínico Silva Araújo, 1958. p. 169-170.

CORREA, M. P - Dicionário das plantas úteis do Brasil e das espécies cultivadas. Rio de Janeiro, Imprensa Nacional, 1931. v. 3. p. 514-516. 
EICHLER, G. A. - "Bixaceae" in Flora Brasiliensis. Martius (EICHLER, G. A. \& URBAN, I.). Monachii. Lipsiae, 1841/1872. v. 8, 1 p. 420-515.

ELFSTRAND, M. - Apud HEgNAUER, R. Chemataxonomie der Pflanzen. Stuttgart, Birkhäusৎr Verlag Basel, 1966. v. 4. p. 167.

ERDTMAN, G. - Pollen morphology and plant taxonomy Angiosperms. $2^{\text {nd }}$ ed. New York and London, Hafner publishing Company, 1966. 539 p.

ESAU, K. - Plant Anatomy. 2 $2^{\text {nd }} \in d$. New Ycrk, John Willey \& Sons. Inc., 1965. $767 \mathrm{p}$.

FARMACOPkiA DOS ESTADOS UNIDOS DO BRASIL - 2. ${ }^{a}$ ed. São Paulo. Gráfica Siqueira, 1959.

FOSTER, A. S. - Practical plant anatomy. New York. D. van Nostrand Co., Inc., 1949. 228 p.

FREISE, F. W. - Plantas medicinais brasileiras. Bol. Agric. São Paulo, 1934. p. $360-361$.

GILG, E. - "Flacourtiaceae" in ENGLER, A. \& PRANTL, K. Die Naturlichen Pflanzenfamilien, $2^{\text {nd }}$ ed. Lcipzig, Verlag von Wilhelm Engelmann, 1925. v. 21. p. $277-456$.

HAUMAN, L. - Esquisse phytogéographique de l'Argentine subtropicale. Bull. Soc. Bot. Belg?. Bruxelles, 64(1) :23-29, 1931.

HARDER, R. \& col. - Strasburgcr's Textbook of Botany. 2nd ed. Trad. Peter Bell e David Coombe. Great Britain; Richard Clay (The Chaucer Press), Ltd., 1967. 846 p.

HOEHNE, F. C. - Plantas e substâncias vegetais tóxicas e medicinais. São Paulo. Graphicars, 1839. p. 1С6-199.

HOEHNE, F. C.; KUHLMANN, M. \& HANDRO, O. - o Jardim Botânico de São Paulo. Secr. Agr. 1941. p. 518.

HOOKER, J. B. \& JACKSON - Index Kewensis plantarum phanerogamarum. Oxford, Clarendon Press, 1895. v. 1. p. 449.

JENSEN, W. A. - Botanical histochemistry-principles and practice. São Francisco, W. H. Freedman and Co., 1ऽ62. 408 p.

JOHANSEN, D. A. - Plant microtechnique. New York and London, McGrawHill Book Co., Inc., 1940. 523 p.

JOLY, A. B. - Botânica: introdųão à taxonomia vegetal. São Paulo, Ed. Nacional, 1966 . p. 392-395.

KUHLMANN, J. G. - Apud AGUIAR, P. - O óleo de chaulmugra e as Flacourtiaceas do Brasil. An. Fac. Med. S. Paulo, São Paulo, 1:337, 1926.

LE COINTE - Amazônia brasileira, árvores e plantas úteis. São Paulo, Ed. Nacional, 1947. v. 3. p. 433.

LINDMAN, C. A. M. - A vegetação do Rio Grande do Sul. Trad. A. Löfgren. Porto Alegre, Typcgraphia da Livraria Universal, 1966. 356 p.

LÖFGREN, A. - Manual das famílias naturais phanerogamas. Rio de Janeiro. Imprensa Nacional, 1917. p. 350. 
LÖFGREN, A. - Ensaio para uma synonimia dos nomes populares das plantas indígenas do Estado de São Paulo. Bol. Comm. Geogr. Geol. São Paulo, 10:69, 1894.

MELCHIOR, H. - in ENGLER, A. - Syllabus der Pflanzenfamilien. Berlin, Gebrüder Borntraeger, 1964. v. 2. p. 323.

METCALFE, C. R. \& CHALK, L. - Anatomy of Dicotyledons. Oxford, Clarendon Press, 1950. p. 116-123.

MINGólA, Q. - Química farmacêutica. Sāo Paulo, Melhoramentos, 1E67. p. 787.

MOLISH, H. - Mikrochemie der Pflanze. Jena, Verlag von Gustav Fischer, 1923. $438 \mathrm{p}$.

MORS, W. B. \& RIZZINI, C. T. - Useful plants of Brazil. San Francisco, Day Inc., $1966.166 \mathrm{p}$.

POSSOLO, H. \& FERREIRA, C. - Saponinas e outros compostos interessantes na Família das Flacourtiaceae. An. Fac. Farm. e Odont. USP, São Paulo, $7: 377-385,1949$.

RECORD, S. J. \& HESS, R. W. - Timbers of the New World. New Haven, Yale University Press, 1942. p. 170-172.

SANTOS, C. F. O. - Morfolog:a e valor taxonômico do pólen das principais plantas agrícolas. Tese. Piracicaba, 1961. $61 \mathrm{p}$.

SASS, J. E. - Botanical microtechnique. $2^{\text {nd }}$ ed. Iowa, The State College Press, 1951. 228 p.

SILVA, R. A. D. da - Farmacopéia dos Estados Unidos do Brasil. Sāo Paulo, Ed. Nacional, 1926 . p. 503-504.

SILVA, G. A. A. B. \& BAUER, L. - Análise do óleo essencial de "Casearia silvestris" SW-I. Rev. bras. Farm. Guanabara, nov./dez. 6:327-331, 1970.

SLEUMER, H. - Las Flacourtiaceas Argentinas. Lilloa. Túcuman, Argentina, 26:5-56, 1953.

STAHL, E. - Thin-Layer chromatography. New York, Springer Verlag Berlin Heidelberg, 1969. p. 857.

THONNER, F. - The flowering plants of Africa. London, Dulan \& Co. Ltd., 1915. p. 367.

WASISKY, R. - Uma modificação do aparelho de Clevenger para extração de óleo essencial. Rev. Fac. Farm. Bioquim. Univ. S. Paulo, I(1):77-81, 1؟63.

WASICKY \& Col. - Fitoquímica de Tabebuia sp. (Ipê-Roxo). Análise de alguns princípios. Rev. Fac. Farm. Bioquim. S. Paulo, jul./dez., 5(2):383-395, 1867.

WASICKY, R. - Estudo farmacognóstico da folha de Psidium cattleyanum Sabine. Tese. São Paulo, 1959. 777 p. 